\title{
Squids of the North: Gastronomy and gastrophysics of Danish squid
}

Faxholm, Peter Lionet; Schmidt, Charlotte Vinther; Brønnum, Louise Beck; Sun, Yi Ting; Clausen, Mathias P.; Flore, Roberto; Olsen, Karsten Bæk; Mouritsen, Ole G.

Published in:

International Journal of Gastronomy and Food Science

Link to article, DOI:

10.1016/j.ijgfs.2018.11.002

Publication date:

2018

Document Version

Peer reviewed version

Link back to DTU Orbit

Citation (APA):

Faxholm, P. L., Schmidt, C. V., Brønnum, L. B., Sun, Y. T., Clausen, M. P., Flore, R., Olsen, K. B., \& Mouritsen, O. G. (2018). Squids of the North: Gastronomy and gastrophysics of Danish squid. International Journal of Gastronomy and Food Science, 14, 66-76. https://doi.org/10.1016/j.ijgfs.2018.11.002

\section{General rights}

Copyright and moral rights for the publications made accessible in the public portal are retained by the authors and/or other copyright owners and it is a condition of accessing publications that users recognise and abide by the legal requirements associated with these rights.

- Users may download and print one copy of any publication from the public portal for the purpose of private study or research.

- You may not further distribute the material or use it for any profit-making activity or commercial gain

- You may freely distribute the URL identifying the publication in the public portal 


\section{Author's Accepted Manuscript}

Squids of the North: Gastronomy and gastrophysics of Danish squid

Peter Lionet Faxholm, Charlotte Vinther Schmidt, Louise Beck Brønnum, Yi-Ting Sun, Mathias P. Clausen, Roberto Flore, Karsten Olsen, Ole G. Mouritsen

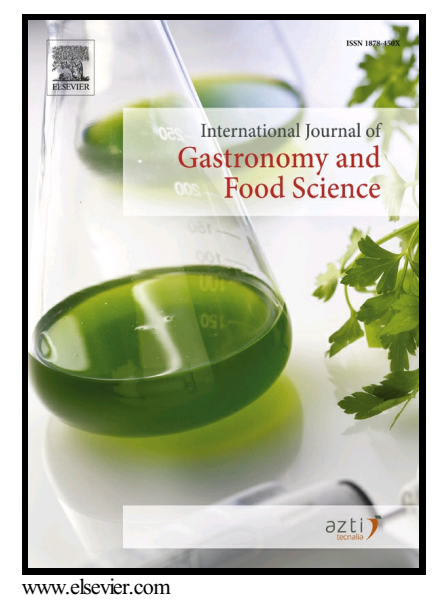

PII: $\quad$ S1878-450X(18)30128-8

DOI: $\quad$ https://doi.org/10.1016/j.ijgfs.2018.11.002

Reference: IJGFS123

To appear in: International Journal of Gastronomy and Food Science

Received date: 3 September 2018

Revised date: 15 November 2018

Accepted date: 15 November 2018

Cite this article as: Peter Lionet Faxholm, Charlotte Vinther Schmidt, Louise Beck Brønnum, Yi-Ting Sun, Mathias P. Clausen, Roberto Flore, Karsten Olsen and Ole G. Mouritsen, Squids of the North: Gastronomy and gastrophysics of Danish squid, International Journal of Gastronomy and Food Science, https://doi.org/10.1016/j.ijgfs.2018.11.002

This is a PDF file of an unedited manuscript that has been accepted for publication. As a service to our customers we are providing this early version of the manuscript. The manuscript will undergo copyediting, typesetting, and review of the resulting galley proof before it is published in its final citable form. Please note that during the production process errors may be discovered which could affect the content, and all legal disclaimers that apply to the journal pertain. 
Paper submitted to the special issue

Gastro-Science-Chef

Int. J. Gastronomy Food. Sci. (2018)

\section{Research paper}

\section{Squids of the North: gastronomy and gastrophysics of Danish squid}

Peter Lionet Faxholm ${ }^{\mathrm{a}^{*}}$, Charlotte Vinther Schmidt ${ }^{\mathrm{a}^{*}}$, Louise Beck Brønnum $^{\mathrm{b}}$, Yi-Ting Sun ${ }^{\mathrm{a}}$, Mathias P. Clausen ${ }^{\mathrm{c}}$, Roberto Flore ${ }^{\mathrm{d}, \mathrm{e}}$, Karsten Olsen $^{\mathrm{a}} \&$ Ole G. Mouritsen ${ }^{\mathrm{a}, * *}$

${ }^{a}$ Department of Food Science, Design and Consumer Behavior, Nordic Food Lab, Taste for Life, University of Copenhagen, Rolighedsvej 26, DK-1958 Frederiksberg C, Denmark

b Alchemist, Refshalevej 173C, DK-1432 Copenhagen

${ }^{\mathrm{c} D e p a r t m e n t}$ of Chemical Engineering, Biotechnology, and Environmental Technology, SDU Biotechnology, University of Southern Denmark, Campusvej 55, DK-5230 Odense M, Denmark

${ }^{\mathrm{d} N o r d i c}$ Food Lab, University of Copenhagen, Rolighedsvej 26, DK-1958 Frederiksberg $C$, Denmark

${ }^{\mathrm{e}}$ DTU SkyLab, Diplomvej,Bygning 373A, DK-2800 Kongens Lyngby, Denmark

\section{Abstract}

Several species of cephalopods, particularly squid, are present in Danish waters, but neither are they fished commercially nor are they part of the Danes' traditional diet. However, if Danes can eat octopus, squid, and cuttlefish when visiting Southern Europe why do they hesitate to eat Danish cephalopods at home? Cephalopods are a nutritious, healthy, and sustainable source of seafood. Moreover, the populations of all species of cephalopods are globally on the rise in stark contrast to the dwindling traditional fisheries. Eating more of them is a way to a more insightful and sustainable use of the marine food resources. The challenge is how to prepare them into delicious 
food and how to make the Danish population, the fishermen, and the retailers aware of their great potential and value as sustainable and delicious food. We have combined scientific gastrophysical investigations of various squid preparations with gastronomical design, innovation, development of recipes, and inventive product design to furnish a solid basis for spreading knowledge, appreciation of flavour, and a desire to consume Danish squid in Denmark.

Keywords: Squid, gastrophysics, gastronomy, flavour, umami, texture, recipes

*These authors contributed equally to the work

**Corresponding author

Email address: ole.mouritsen@food.ku.dk (O. G. Mouritsen)

\section{Introduction}

Whereas cephalopods (squid, cuttlefish, and octopus) have a long tradition and are common in the gastronomy and food cultures of Southern Europe and South East Asia (Mouritsen and Styrbæk, 2018a: 2018b) they are virtually absent in the food cultures of Northern Europe. This is particularly striking considering that many cephalopod species are common in the North Atlantic Ocean and the North Sea. Traditionally, cephalopods are not the target of the otherwise very extensive fisheries in, e.g., the Scandinavian countries. Abundance of specific food resources is however not the only determinant of what enters a particular food culture. Tradition is a key factor, and it so happens that there is little tradition for consuming squid, cuttlefish, and octopus in Scandinavia, including Denmark, even if these countries are basically immersed in water and have a millennia-long strong tradition for fisheries that easily could have cephalopods on their catch list. Although some species of cephalopods are caught, it is mostly as a bycatch in the nets of the trawlers and only little of the catch ends up on local dinner tables.

However, food cultures can change over time, albeit often very slowly. One driving force for changing food cultures is the globalization of eating habits that are strongly influenced by travel, tourism, migration, and international trade. As an example, expanding charter tourism and package tours for Danish tourists to Southern Europe from the 1960ies brought many Danes in contact with, e.g., Spanish, Italian, and 
Portuguese cuisines and their extensive use of cephalopods. Inspired from the south, squids got introduced to the Scandinavian countries as fried and battered squid rings, sold as fast food and at cheap restaurants. These squid rings, although in some cases delicious, are most often perceived by customers as greasy and imparted with a rubbery texture. A bad experience with unpleasant texture can create an aversion and may be one of the reasons why cephalopods have not succeeded on the Danish market.

In order to inspire Danes to start eating cephalopods, one of the authors (OGM) teamed up with chef Klavs Styrbæk in 2016-2017 to write a monograph about cephalopods, combining cultural history, natural science, and nutritional aspects with gastronomy, cooking, and culinary sciences (Mouritsen and Styrbæk, 2018a). Surprisingly, such a monograph did not exist before, even so internationally, and in fact only a few, mostly rather old cookbooks, primarily covering Asian cuisines, are available (Cronin, 1981; Schultz and Regardz, 1987). Later, in October 2017, an international research team was formed (the so-called Squid Squad, or 'Blækspruttebanden' in Danish) at Nordic Food Lab and the Department of Food Science at the University of Copenhagen. The team consisted of an interdisciplinary group of physical and chemical scientists, chefs, students, and interns (all authors of the present paper) who decided to explore the gastronomical potential of Nordic squids available to Danish fisheries, mostly the decapod Loligo forbesii, with a special focus on texture and taste.

The perspective of the work could be seen in the context of the New Nordic Cuisine whose goal is to explore the Nordic terroir, not least the marine environment, and seek deliciousness in little used food resources (Evans et al., 2015). A further motivation for the work derived from a wish to use the local marine resources in more insightful and sustainable ways, a search for untapped low-fat protein sources to replace meat from land animals, as well as a general desire to expand the range of the general public's acceptation of what might be considered edible. An overarching inspiration to undertake this work was the recent findings that all cephalopod populations, in contrast to many fish populations, are globally on the rise and have been so for the last sixty years (Doubleday et al. 2016), possibly because of the cephalopods' unique ability to quickly adapt to new habitats and adjust to climatic 
changes. Finally, the relatively short life cycles of cephalopods could make them an attractive marine food source in the future since they tend to accumulate lower levels of potentially toxic heavy metals compared to popularly consumed predatory fish (FDA, 2004; Storelli et al., 2006; 2010).

The results of the work to be described in the present paper consist of a plethora of information derived from quantitative scientific studies of squid texture, taste, chemical composition, and muscle structure. Furthermore, we studied qualitative sensory perception, different and systematic culinary procedures and precisions, as well as examples of novel products that were designed on basis of the obtained insight into squid texture and taste. In line with a sustainable approach, the studies involved all parts of the squids, including mantle, arms, tentacles, fins, head with eyes, buccal mass with beak, retractor muscles attached to the siphon, liver, ink sack, and reproductive organs for females. Since the present paper aims to illustrate the collaboration between scientists and chefs, it will not contain all the details of the scientific methods applied and data obtained. These details will be published separately in specialized scientific journals. This present paper will overview a selected part of the results to illustrate the gastronomical potential of Danish squid, with a focus on sous vide preparation. In addition, we present a few specific culinary precisions (recipes) and indicate some possible innovative products.

The work was part of the activities of the Danish national centre for taste and taste communication, Taste for Life ('Smag for Livet' in Danish), and the results were therefore also processed with a view to disseminate the results to an audience beyond the scientific and the professional gastronomic communities, in particular the general public as well as via popular science and teaching materials for children and young people (see e.g., Schmidt et al., 2018; Mouritsen and Styrbæk, 2018a; Flore et al., 2018).

\section{Occurrence of cephalopods in Danish waters}

Danish waters are here defined as salt-water basins accessible to Danish fishing operation, including the immediate North Sea, Norwegian Trench, and Swedish Bohuslän waters. There exists no complete up-to-date registration of cephalopods in the waters around Denmark but we have estimated that over 44 different species have 
been reported from live catch or drifted ashore dead specimens: 24 species of squid across 13 families, 12 species of sepioid cuttlefish across 2 families, and 8 species of octopus/argonaut across 5 families. In addition to this, a single species (Spirula spirula) from the Spirulida order has been reported from the finding of planispiral shells cast ashore (Muus, 1959).

Some of these 44 species have been found only extremely rarely, and they may only reside in Danish waters for a short period, when they have been hunting a shoal of prey. In Fig. 1 the phylogenetic tree of these species is displayed, highlighting the place of the squid species, Loligo forbesii, which is the main topic of the present paper. The Loligo genus belongs to the Myopsida order of the Decapodiformes superorder.

Fig. 1. Phylogenetic tree of cephalopods found in waters around Denmark (including Spirula spirula), highlighting the species Loligo forbesii that is the main focus of the present paper. Sources: Jereb and Roper (2005; 2010), Jereb et al. (2016), and WoRMS (2018).

In Table 1 is given a compilation of cephalopod species observed in Danish waters with indication of prevalence, seasonal occurrence, edibility, and typical size and mass. The data has been derived from a series of mostly older sources in Danish (Muus, 1959; Jensen and Knudsen, 1995; Jensen, 2005; DanBIF, 2018) and from the little information that is available in FAO documents (Jereb and Roper, 2005; 2010; Jereb et al., 2016). In some cases, the literature is inconsistent for the rarer species.

Table 1. Cephalopod species observed in Danish waters with indication of prevalence, seasonal occurrence, edibility, and typical size and mass. Some of the data for prevalence and seasonal occurrence may be imprecise (e.g., some estimates of mantle size are larger than the equivalent full body estimate) since it is based on qualitative estimates and anecdotal evidence, some possibly outdated. The seasonal variation is graded on a scale 1-10 with a corresponding variation in colour tone. Sources: Muus (1959), Jensen and Knudsen (1995), Jensen (2005), Jereb and Roper (2005; 2010), Jereb et al. (2016), DanBIF (2018), and WoRMS (2018). 


\section{Materials and storage}

\section{Raw squid material}

Fresh Loligo forbesii was purchased from a Danish retail seafood supplier (Fiskerikajen Engros, Rungsted Havn 48, DK-2960 Rungsted Kyst, Denmark). Both females and males were received and their weights were in the range $0.2-4 \mathrm{~kg}$. The squids were caught as by-catch by trawlers in the North Sea (mostly Jammerbugten). The skin often had scratches, implying that they had been closely bunched up in a net, in direct contact with netting or suffered from ungentle handling. Small fish like herring were often found inside the mantle cavity, possibly pushed in during the trawling. A rough division between 'big' and 'small' squids is usually offered by the supplier: big, having a weight of $>800 \mathrm{~g}$, and small, having a weight of $\leq 800 \mathrm{~g}$. We mainly focused on the small ones, since the abundance of younger specimens compared to older specimens would help to ensure a more consistent supply and thus result in more comparable data with less deviation. A standardized thickness is especially important when analysing texture, since squid individuals of different sizes cannot be cut to the same sample thickness due to the different layers of, e.g., structural proteins that run parallel to the surface. Standardized sample size is of crucial importance for measuring the textural profile.

The deliveries from the supplier tended to contain more male than female squids. The reason for this is probably that squids tend to school with squids of similar size, which gives a bias towards a predominant sex in a shoal (can be up to $80 \%$ of a single sex). The larger squids (over $1.6 \mathrm{~kg}$ ) were all male. The overall quality was judged from a fresh smell, and no visual appearance of parasites. The hazard from any possible parasites was minimized by freezing the squid before tasting. The $\mathrm{pH}$ was monitored and the temperature varied from 2.4 to $4^{\circ} \mathrm{C}$.

\section{Cleaning, dissecting, and storage of raw material}

Whole squids were placed on ice and stored in the fridge until being cleaned and cut. The squids were cleaned and weighed, and size was noted during cleaning. The whole squid was dissected in various parts, cf. Figs. 2, 3, and 4 (mantle, arms, tentacles, fins, head with eyes, buccal mass with beak, retractor muscles, siphon, hearts, liver, ink sack, and reproductive organs (nidamental glands, accessory nidamental glands, 
oviductal glands, and egg sacks for females)). Male reproductive system and digestive systems of both sexes (including stomach, cecum, and rectum) and circulatory/respiratory organs (hearts and gills) were discarded. All parts were kept on ice until packed, sealed by vacuum in plastic pouches, frozen in a blast freezer ($20^{\circ} \mathrm{C}$ ), and kept at $-20^{\circ} \mathrm{C}$ at least 48 hours before use in gastronomical experiments and for tasting. Samples for microscopy and chemical analysis were stored at $-40^{\circ} \mathrm{C}$ before subject to analysis and thawed right before use.

Fig. 2. Specimen of Loligo forbesii where the mantle is cut open to display part of the innards, including ink sack, hepatopancreas (liver), and gills. The chitinous gladius has been removed and is shown on the side. (Permission to print by courtesy of Jonas Drotner Mouritsen.)

Fig. 3. The eight arms and two tentacles of a specimen of Loligo forbesii with the buccal mass and the beak at the centre. One of the arms show a clear hectocotylus with absent suckers at the end of the arm. (Permission to print by courtesy of Jonas Drotner Mouritsen.)

Fig. 4. Schematic illustration of the anatomy of a squid. (Permission to print by courtesy of Jonas Drotner Mouritsen.)

\section{Culinary transformations}

We have subjected the different parts of the squids to different culinary transformations, such as freezing at different temperatures (including blast freezing and use of liquid nitrogen), thawing, freeze-drying, sous vide cooking, steaming, drying, salting, frying, smoking, candying, and confiting. Furthermore, we have performed fermentation trials using different enzymes, including squid intestinal juices from hepatopancreas (ika no shiokara), squid ink, juices from fruit and dairy, and koji. The focus has been on evaluating qualitatively as well as quantitatively the resulting taste and texture subsequent to applying these procedures. Special attention has been paid to tenderization of muscle tissue (mantle, fins, retractor muscles, arms, and tentacles). The physiochemical and organoleptic properties of the different preparations were studied systematically and quantitatively by a wide range of 
different techniques, including texture analysis, microscopy, chemical analysis, and quick sensory evaluation.

\section{Structure characterization}

Microscopy

Squid contain more connective tissue than both fish and terrestrial animals. The strength of the connective tissue is key to determining the texture of the prepared squid. The connective tissue is composed mainly of a network of collagen fibrils that are long protein fibres wrapped in a tri-helical structure (Otwell and Giddings, 1980). The tri-helical structures assemble in larger bundles, and the strength of the crosslinks both within and between fibres determines the overall strength of the connective tissue. The highly ordered molecular structure of collagen fibrils and the lack of optical symmetry gives collagen the ability to interact with light in a non-linear fashion and behave as a second-harmonic generation (SHG) material (Chen et al., 2012). When illuminated with strong laser light, SHG materials can 'combine' two incoming photons to one and generate light with exactly half the wavelength of the incoming light. This can be used to image the structure of squid muscles and determine how the microscopic organization of collagen changes during preparation. SHG microscopy has several advantages; it uses an intrinsic property of collagen fibrils and therefore is non-invasive, and it uses far-red laser light. Hence it can penetrate deep inside tissue, and the two-photon process gives a sub-micrometer sectioning effect.

\section{Preparation of samples}

Raw and sous vide prepared mantle of Loligo forbesii were frozen at $-20^{\circ} \mathrm{C}$ before preparation for microscopy. A piece of the frozen mantle was cut laterally near the centre using a sharp razor blade. The cut surface of the now thawed mantle sample was placed on a \#1.5 cover glass and then immediately imaged. Second-harmonic generation (SHG) microscopy was performed on a Leica SP8 microscope (Leica Microsystems GmbH, Mannheim, Germany) equipped with an OPO (optical parametric oscillator) tunable picoEMERALD multiphoton laser (APE, Berlin, Germany) and using a 40X HC PL IRAPO 1.10 NA Leica objective. The laser was set to $1050 \mathrm{~nm}$, and signal was collected in the backscatter mode on a photomultiplier 
tube (PMT) detector with a 525/50 bandpass filter in front. Imaging was done at room temperature $\left(22^{\circ} \mathrm{C}\right)$.

\section{Collagen structure}

The microscopy images in Fig. 5 show the collagen structure in a mantle of Loligo forbesii in raw state and after sous vide preparation at $55^{\circ} \mathrm{C}$ for $30 \mathrm{~min}$. In the raw mantle, the collagen fibres generate a strong second-harmonic signal reflecting the high degree of molecular order. The collagen organizes in a dense network of long linear bundles that entangle in the lateral direction in a roughly perpendicular manner (Fig. 5A). After sous vide treatment for $30 \mathrm{~min}$, the signal significantly decreases indicating that the heat treatment affects the molecular structure of the collagen as the squid becomes more tender. Still, a few intact collagen fibres are seen surrounded by what appears to be partly or fully denatured collagen (Fig. 5B).

Fig. 5. Second-harmonic microscopy images of collagen structure of the squid mantle. The scale bars correspond to $50 \mu \mathrm{m}$. Before (A) and after (B) sous vide treatment at $55^{\circ} \mathrm{C}$ for $30 \mathrm{~min}$.

\section{Texture characterization}

Texture analysis

Texture analysis is applied in several different industries, as it can measure specific features and characteristics related to the way a material bends, flows, sticks, or breaks. Depending on the chosen method (compression, shearing, etc.) and corresponding probe (cylinder, knife-blade, etc.) it is possible to measure various textural parameters. The obtained result from texture analysis is a graph displaying the relationship between the applied force of the texture analyser and the deformation of the tested material over time of deformation for a given loading rate. Interpretation of the results can yield information about hardness, springiness, toughness, stickiness, crispiness, etc.

For texture analysis of squid, we measure the maximum force needed to shear the squid meat (shear force) as well as calculating the area below the force vs. time graph (toughness) in a defined interval. The shear force and toughness can be used to reveal information about tenderness as they are oppositely correlated. Texture analysis may 
be correlated with results from microscopy, as the applied force of the probe depends on the structure and state of the collagen network inside the meat.

\section{Textural changes during sous vide}

Samples for texture analysis were cut from the middle, ventral part of the mantle of raw squid (cf. Fig. 6) obtaining as uniform sizes of samples as possible. The samples were then prepared by sous vide $\left(55^{\circ} \mathrm{C}\right)$ with different cooking times $(0,0.5,1$, and $1.5 \mathrm{hr}$ ) and then cooled to $5^{\circ} \mathrm{C}$ before analysis. The samples were additionally cut into even sizes of $1.5 \times 1.5 \mathrm{~cm}$ cubes and then measured with a TA.XT.plus texture analyzer (Stable Micro Systems, Godalming, Surrey, UK) using a Warner Bratzler Blade Set (ib.). The probe is applied to the inside of the mantle and the orientation of the blade probe is parallel to the circular fibres of the mantle.

The results indicate that there is a clear effect of sous vide preparation on the tenderness of the squid mantle and that different cooking times have different outcomes (cf. Fig. 7). Thus, the longer sous vide cooking, the less shear force was required to shear the samples. The different sous vide cooking times also revealed that longer cooking times yielded a more uniform shearing, whereas shorter cooking times maintained textural differences throughout the shearing, i.e., having a difference in texture throughout the different layers of the mantle. Since the texture analysis does not reveal any information about how textural profiles may be perceived by humans, samples were also evaluated sensorially with regard to taste and texture by our own team of researchers. A so-called quick-method (Delarue et al., 2015) developed and modified specifically for the purpose was used to find attributes of taste, texture, and mouthfeel, which were noted for each sample in order to compare and rank samples against each other. The results of this evaluation revealed that despite the fact that the longest cooking time resulted in the most tender texture profile, this preparation was not the most liked. Sensory evaluation demonstrated that a relatively short cooking time (but not raw) was preferred as it yielded a better taste and a more stimulating texture during mastication, whereas longer cooking times yielded an over-cooked surface, a bitter taste, and a dull mouthfeel throughout mastication.

Fig. 6. Sectioning of squid mantle for texture analysis. 
Fig. 7. Force versus time at loading rate $2 \mathrm{~mm} / \mathrm{s}$ for a squid mantle sample before and after sous vide treatment $\left(55^{\circ} \mathrm{C}\right.$ for $0.5,1.0$, and $\left.1.5 \mathrm{hrs}\right)$.

\section{Textural changes during freeze storage}

Freeze storage of squids below $-20^{\circ} \mathrm{C}$ for at least $24 \mathrm{hrs}$ is recognized to kill parasites (nematodes) that may occur in all fishery products and therefore also squids. Furthermore, some rumours among chefs say that freezing of squid enhances tenderness and eating quality of the meat. However, the general belief is that freeze storage of meat impairs the quality of meat by decreasing tenderness and inducing leakage of water.

Preliminary results of our texture analysis indicated that when squid is intended to be eaten raw, it may indeed be tenderized if frozen at $-20^{\circ} \mathrm{C}$ for $48 \mathrm{hrs}$. When first blast freezing to $-20^{\circ} \mathrm{C}$ and then freezing at $-40^{\circ} \mathrm{C}$ for $48 \mathrm{hrs}$, the tenderness does not substantially change, i.e., the lower temperatures do neither have a positive nor a negative effect on perceived eating quality. However, when cooking the squid (standardized treatment by steaming in an oven at $70^{\circ} \mathrm{C}$ for $5 \mathrm{~min}$ ) after freeze storage, preliminary results show that freezing slightly impairs tenderness, but to a lesser degree for storage at $-20^{\circ} \mathrm{C}$ than at $-40^{\circ} \mathrm{C}$, and less for a prolonged storage (2-8 weeks) compared to short-term storage ( $48 \mathrm{hrs).} \mathrm{Thus,} \mathrm{when} \mathrm{eating} \mathrm{squid} \mathrm{raw,} \mathrm{it} \mathrm{may}$ be beneficial to apply short-term freeze storage at $-20^{\circ} \mathrm{C}$ to kill parasites as well to increase tenderness. However, when eating squid cooked, storage for a longer time compared to short time, may primarily be advised in order to secure food safety, only inflicting little negative change in tenderness.

\section{Taste compounds}

Amino acid analysis by UHPLC

To evaluate part of the taste profile of our squid preparations, we measured the amino acid composition of squid mantle. Free amino acids are known to elicit taste and can be divided into categories, where Asp and Glu (in ionic form) can be perceived to yield umami flavour, Ala, Gly, Thr, Ser, Pro, Asn, and Gln yield sweetness, and Val, Leu, Ile, Met, His, and Trp and Arg cause bitterness (Kawai et al., 2012). When bound in large proteins, the amino acids have no taste. However, the total composition of amino acids of a sample will indicate its taste potential that can 
possibly be realized by hydrolytic break-down of the proteins, e.g., by certain culinary processes such as fermentation.

Amino acid analysis can be performed by various methods applying different extraction techniques prior to analysis. In our work, the procedure of extraction and the following free amino acid analysis (FAAA) as well as total amino acid analysis (TAAA) used an optimized method for squid meat based on a method previously developed for mushrooms (Poojary et al., 2017). The analysis was carried out by the use of Ultra-High-Performance Liquid Chromatography (UHPLC) Dionex UltiMate 3000 (Thermo Fisher Scientific, Waltham, USA). Sample preparation for TAAA was conducted utilizing microwave (MW) hydrolysis using a Biotage Initiator+ (Biotage $\mathrm{AB}$, Uppsala, Sweden), which is a more efficient alternative to conventional hydrolysis.

Preliminary results for raw squid mantle showed a relatively high content of sweet tasting free amino acids in FAAA (Ala, Gly, Thr, and Ser) and a relatively high content of umami-potent free amino acids (Asp and Glu) in TAAA, cf. Fig. 8. This may indicate that the sweet taste known from fresh raw squid to some extent is caused by the presence of sweet free amino acids. Furthermore, squids may have a great potential for umami taste when prepared, through hydrolysing and liberating the relatively high amount of Glu and Asp. Further investigations are needed to indicate which preparation techniques yield the most desirably possible amino acid profile outcome.

Fig. 8. Free- and total amino acid composition of raw squid mantle.

\section{Umami taste}

Umami is one of the five basic tastes and it is characterized as a pleasant, savoury flavour (Mouritsen and Styrbæk, 2014). Umami has been correlated to the presence of free amino acids, in particular Glu, that enter in a synergistic relationship with certain free 5'-mononucleotides (Yamaguchi et al. 1971; Zhang et al., 2008; Mouritsen and Khandelia, 2012). Asp is known to have a much weaker umami taste than Glu (Li et al., 2002; Chandrashekar et al., 2006). From our quantitative free amino acid analysis 
of squid mantle we find a free Glu content of $63 \mathrm{mg} / 100 \mathrm{~g}$ (wet weight). This value is somewhat larger than the contents reported from Japanese squid (UIC, 2018), 20$30 \mathrm{mg} / 100 \mathrm{~g}$, a number that presumably is based on whole Japanese flying squid (Todarodes pacificus) and not only mantle. Compared to meat from other seafood, the free glutamate content found in Danish squid is substantially higher than beef $(10 \mathrm{mg} / 100 \mathrm{~g})$ and chicken $(22 \mathrm{mg} / 100 \mathrm{~g})$, but less than in scallop $(140 \mathrm{mg} / 100 \mathrm{~g})$ (Yamaguchi and Ninomiya, 2000).

Similar to other organisms from salty waters, like bonefish and shellfish, squid have many different tastes and flavours, but they share a component of umami taste due to their content of not only free glutamate but also nucleic acids, like ATP, that enzymatically can be turned into free nucleotides such as inosinate and adenylate under the proper conditions after the animal has been killed under reduced stress conditions. Japanese squid has been found to contain high levels of adenylate, up to $184 \mathrm{mg} / 100 \mathrm{~g}$ (Yamaguchi and Ninomiya, 2000), which is about as much as scallops and six times as much as a sun-ripe tomato. The simultaneous presence of both free nucleotides and free glutamate is the precondition for the very potent umami-synergy mechanism coming into play (Mouritsen and Khandelia, 2012). We have not included measurement of free nucleotides in the present study.

\section{Safety issues}

Squid can suffer from the same bacterial and parasitic diseases as bonefish, e.g., Anisakis spp. (Abollo et al., 2001), and the same safety precautions must be taken when dealing with squid as with other types of seafood. The formation of biogenic amines, e.g., histamine derived from the amino acid histidine, is a serious concern in seafood, particularly during storage (Kim et al., 2009; Hu et al., 2012). It turns out, that Danish squid is relatively low in precursor amino acid histidine $(53 \mathrm{mg} / 100 \mathrm{~g}$ in free form and $605 \mathrm{mg} / 100 \mathrm{~g}$ in total as found in the present work). We have not measured the level of histamine in our samples.

An important safety issue of seafood is accumulation of heavy metals, in particular mercury and arsenic in fish and shellfish, and cadmium in squid. Based on an elemental analysis using atomic absorption spectroscopy of $\mathrm{Pb}, \mathrm{Cd}$, and $\mathrm{Hg}$ contents of Danish squid mantle, ink, and fin we found very low values (in the ppb area and 
below). This finding is generally in accord with recent measurements of non-essential, toxic elements ( $\mathrm{HG}, \mathrm{Cd}, \mathrm{Pb}$, and $\mathrm{As})$ in the most commonly consumed species of octopus, squid, and cuttlefish caught in the Mediterranean (Storelli et al., 2006; 2010). That study also found that octopus is the most loaded and squid the least. Hepatopancreas contains the largest amounts of the toxins, except for mercury and arsenic which are equally distributed between innards and muscles. As for arsenic, cuttlefish accumulates the most. However, arsenic is predominantly found in organic form, and Storelli et al. $(2006 ; 2011)$ therefore argue that it is not considered to be of any health concern through human consumption.

\section{Selected recipes}

Raw squid paste

The most dramatic change of the texture and the most pristine taste of squid result from complete homogenization of the mantle into a paste that is eaten raw. The sweet taste of the muscle then comes forward to an extent that the paste can even be used for a sweet desert. Below is described a recipe for a Sardinian-inspired pane carasau (traditional flat bread) wafer with raw squid paste.

A mantle without skin is blast frozen and then cut in smaller pieces and placed in a canister and processed two to three times in a Pacojet with freezing in between. The resulting paste is kept in the freezer until use. A piece of pane carasau is wetted and stamped into $4 \mathrm{~cm}$ circular pieces. The pieces are brushed with melted butter, dusted with icing sugar, glazed in an oven at $200^{\circ} \mathrm{C}$ for $4 \mathrm{~min}$, and then cooled to room temperature. The squid paste is placed on top of the pane carasau with a few drops of lemon verbena oil and possibly a little powder of dried salted capers, cf. Fig. 9. A macerated Sardinian Malvasia wine is a perfect companion to this serving.

Fig. 9 Raw squid paste on Sardinian pane carasau. (Permission to print by courtesy of Jonas Drotner Mouritsen.)

\section{'Silk squid' (curly mantle confit)}

Cooking squid in oil is a way to both tenderize the mantle and to preserve it as a confit. The mantle is cut into thin strips along the long axis. The difference in the muscular structure at the surface and the inner part of the mantle makes the strips 
contract unevenly in the hot oil with the result that the product ends up with an appealing curly appearance. By adding fat to the very lean squid meat, a much smoother texture can be obtained compared to equivalent low-fat cooking methods.

The mantle is cut with a sharp knife from top to bottom in 1-2mm thin strips. The thinner the strips, the curlier the product. The squid strips are cooked in a pot with sunflower seed oil at $85^{\circ} \mathrm{C}$ in $35-40$ min depending on the thickness of the mantle. It is important in the beginning to gently stir the mixture so a desirable degree of curling results. The final product is drained on oil-absorbing paper, after which the curly squid strips are silky soft. It can be served as is with lemon juice, chopped parsley, salt, and pepper (cf. Fig. 10). The curly squid can also be served cold, like pasta, in a cold salad.

Fig. 10 'Silk squid' (curly mantle confit) of squid mantle strips. (Permission to print by courtesy of Jonas Drotner Mouritsen.)

\section{Tentacle braids}

Squid tentacles were braided three and three, sealed in vacuum bags, and steamed at $70^{\circ} \mathrm{C}$ for 5 minutes. $3 \%$ salt $(\mathrm{w} / \mathrm{w})$ were added, and the braids were then cold smoked for 1.5-2 hours. Subsequently, the braids were cured in a curing chamber at $2^{\circ} \mathrm{C}$ with $65 \% \mathrm{RH}$ (relative humidity) for 1-2 days until about $40 \%$ water loss was obtained. This preparation results in a beautiful product with an aesthetic and pleasing appearance, cf. Fig. 11, and a tender but still firm mouthfeel similar to cured ham.

Fig. 11 Braided squid tentacles, steamed, cold smoked, and cured. (Permission to print by courtesy of Jonas Drotner Mouritsen.)

\section{Semi-dry squid}

Squid mantles were steamed at $70^{\circ} \mathrm{C}$ for $3 \mathrm{~min}$, pat-dried, and then marinated in a mixture of seasonings including salt overnight at $2^{\circ} \mathrm{C}$. The next day, the squids were transferred to a dehydrator at $45^{\circ} \mathrm{C}$ for a period of 4.5 hours, during which the mantles were turned over once after the first 2.5 hours. After the dehydration, the water content of squids is about $40 \%$. The mantles were roasted in between two aluminium 
flat baking trays preheated at $110^{\circ} \mathrm{C}$ and roasted at $110^{\circ} \mathrm{C}$ for 10 minutes until brown, especially on the edges. They were then cold-smoked for 1.5-2 hours, vacuum sealed and stored at $2{ }^{\circ} \mathrm{C}$ until use, but for a minimum of 24 hours, which results in a more uniform texture and no dry edges. This type of preparation of squid mantles is related to the classical Japanese ika no ichiya-boshi, cf. Fig. 12. The semi-dried squid pieces can be pulled into threads and be used as a snack or similarly to surimi.

Fig. 12 Semi-dry squid mantles that have been cut in strips and grilled. (Permission to print by courtesy of Jonas Drotner Mouritsen.)

\section{Product development}

The recipes given above could readily be implemented for use in an innovative gastronomic series of products based on Danish squid. The insight into details of the muscular structure of the different tissues, as well as how various enzymatic processes tenderize it, are also expected to form a basis for industrial applications. As an example, Fig. 13 displays a prototype of a canned product with prepared, small squid arms. Furthermore, the full study of the gastronomic potential of Danish squid exploring not only the mantle and the arms but also buccal mass, retractor muscles, reproductive organs, hepatopancreas, and reproductive organs, holds the potential for using most of the whole squid as valuable and delicious foodstuff leading to less waste of the catch.

Fig. 13 Canned prototype product of prepared, small squid arms in oil. Label design with gyotaku print of the squid tentacle club. (Permission to print by courtesy of Jonas Drotner Mouritsen.)

\section{Public dissemination and outreach}

The present project was carried out as part of the activities at the national Danish centre for taste studies and taste communication Smag for Livet (www.smagforlivet.dk). The results were disseminated via a number of different activities, including the writing of popular science articles (Schmidt et al., 2018; Flore et al., 2018), a scientific review (Mouritsen and Styrbæk, 2018b), communication with chefs (Flore et al., 2018) and fishermen via hands-on workshops, as well as 
production of teaching materials and courses for elementary school and high school children (www.smagforlivet.dk).

\section{Conclusions and outlook}

In the present topical review we have described some of the results obtained during an interdisciplinary project aimed at exploring the gastronomical potential of Danish squid (Loligo forbesii), which is the most common cephalopod in Danish waters. The project was executed as a tight collaboration between chefs and scientists with the aim and vision of uncovering the possible uses of a poorly exploited marine food resource in the Nordic area. By combining culinary arts, gastronomy, and gastrophysics we have provided a knowledge base for chefs, gastronomical entrepreneurs, and producers to aid further development of novel products utilizing the so far little used, but plentiful resource of squid in Danish waters. A particular emphasis has been put on using all parts of the squid, including the innards (although not presented in this paper) that often are discarded by fish mongers and consumers. In the paper we have focused on the taste and texture of particularly the squid mantle. We have revealed the umami potential of the squid and presented well-defined culinary procedures that lead to particularly attractive mouthfeel such as smooth, soft, and tender. We have characterized the texture and collagen structure of the mantle, and described how it changes during heat treatment, leading way to a better understanding of which factors control texture. Finally we have found that the environmental load of toxic heavy metals is very low. Further details of the quantitative analysis of other parts of the squid will be presented separately.

We expect that by communicating our scientific results along with a more popular dissemination program, the fishing industry, retailers, and the consumers will increase their interest in Nordic squid as a delicious, possibly more sustainable marine food resource that may replace part of the meat consumption from fish and land animals.

We believe that the present work demonstrates an example of the way the interaction between chefs and scientists can proceed fruitfully by taking a starting point in the culinary world and posing a gastronomic question (what controls taste and texture of squid?), then seek possible answers by applying a variety of scientific methods, and finally bringing the obtained results back into the kitchen, to exploit the combined 
new insight in order to develop novel recipes and products of increased gastronomic value.

\section{Acknowledgments}

This work was supported in part by a grant to Smag for Livet (Taste for Life) from Nordea-fonden.

Declarations of interest: none.

\section{References}

Abollo. E., Gestal, C., Pascual, S.S., 2001. Anisakis infestation in marine fish and cephalopods from Galician waters: an updated perspective. Parasitol. Res. 87, 492499.

Chandrashekar, J., Hoon, M. A., Ryba, N. J., Zucker, C.A., 2006. The receptors and cells for mammalian taste. Nature 444, 288-294.

Second harmonic generation microscopy for quantitative analysis of collagen fibrillar structure

Chen, X., Nadiarynkh, O., Plotnikov, S., Campagnola, P.J., 2012. Second harmonic generation microscopy for quantitative analysis of collagen fibrillar structure. Nature Protocols 7, 654-669.

Cronin, I., 1981. The International Squid Cookbook. Aris Books, New York.

DanBIF, 2018. Danish Biodiversity Information, University of Copenhagen, Denmark. http://allearter-databasen.dk/?artsgruppe=Cephalopoda\&arter $=1 \&$. Accessed on August 24, 2018.

Delarue, J., Lawlor, B., M Rogeaux, M. (eds.), 2015. Rapid Sensory Profiling Techniques: Applications in New Product Development and Consumer Research. Woodhead Publishing, Cambridge.

Doubleday, Z.A., Prowse, T.A.A., Arkhipkin, A., Pierce, G.J., Semmens, J., Steer, M., Leporati, S. C., Lourenço, S., Quetglas, A., Sauer, W., Gillanders, B.M., 2016. Global proliferation of cephalopods. Cur. Biol. 26, R406-R407. 
Evans, J., Flore, R., Pedersen, J.A., Frøst, M.B., 2015. Place-based taste: geography as a starting point for deliciousness. Flavour 4:7

FDA, 2004. https://www.fda.gov/food/foodborneillnesscontaminants/metals/ucm351781.htm.

Flore, R., Brønnum, L. B., Mouritsen, O.G., 2018. På blækspruttejagt på Sardinien. GASTRO 140, 72-76.

Hu., Y., Z. Huang, Li, J., Yang, H., 2012. Concentrations of biogenic amines in fish, squid and octopus and their changes during storage. Food Chem. 135, 2604-2611.

Kawai, M., Sekine-Hayakawa, Y., Okiyama, A., Ninomiya, Y., 2012. Gustatory sensation of L- and D-amino acids in humans. Amino Acids 43, 2349-2358.

Jereb, P., Roper, C.F.E. (eds.), 2005. Cephalopods of the world. An annotated and illustrative catalogue of cephalopod species known to date. Volume 1. Chambered Nautiluses and Sepioids (Nautilidae, Sepiidae, Sepiolidae, Sepiadariidae, Idiosepiidae and Spirulidae) FAO Species Catalogue for Fishery Purposes No. 4 , Rome.

Jereb, P., Roper, C.F.E. (eds.), 2010. Cephalopods of the world. An annotated and illustrative cataloguee of cephalopod species known to date. Volume 2. Myopsid and Oegopsid Squids. FAO Species Catalogue for Fishery Purposes No. 4, Rome.

Jereb, P., Roper, C.F.E., Norman, M.D., Finn, J.K. (eds.), 2016. Cephalopods of the world. An annotated and illustrative catalogue of cephalopod species known to date. Volume 3. Octopods and Vampire Squids. FAO Species Catalogue for Fishery Purposes No. 4, Rome.

Jensen, K.R., Knudsen, J., 1995. Annotated checklist of recent marine molluscs of Danish waters. University of Copenhagen, Copenhagen. ISBN 87-7834-108-6.

Jensen, F., 2005.Blæksprutter. Natur og Museum, Aarhus. No. 2, June.

Kim, M.-K., Mah, J.-H., Hwang, H.-J., 2009. Biogenic amine formation and bacterial contribution in fish, squid, and shellfish. Food Chem. 116, 87-95.

Li, X., Staszewski, L., Xu, H., Durick, K., Zoller, M., Adler, E., 2002. Human receptors for sweet and umami taste. Proc. Natl. Acad. Sci. USA 99, 4692-4696.

Mouritsen, O.G., Khandelia, H., 2012. Molecular mechanism of the allosteric enhancement of the umami taste sensation. FEBS J. 279, 3112-3120.

Mouritsen, O.G., Styrbæk, K., 2014. Umami: Unlocking the Secrets of the Fifth Taste. Columbia University Press, New York. 
Mouritsen, O.G., Styrbæk, K., 2018a. Blceksprutterne kommer - spis dem! Gyldendal, Copenhagen.

Mouritsen, O.G., Styrbæk, K., 2018b. Cephalopod gastronomy - a promise for the future. Front. Comm. Sci. Environ. Comm. 3:38.

Muus, B.J., 1959, Skallus, søtænder, blæksprutter. Danmarks Fauna 65, Gads Forlag, Copenhagen.

Otwell, S., Giddings, G.G., 1980. Scanning electron microscopy of squid Loligo pealei: raw, cooked and frozen mantle. Mar. Fish. Rev. July-August.

Poojary, M. M., Orlien, V., Passamonti, P., Olsen, K., 2017: Improved extraction methods for simultaneous recovery of umami compounds from six different mushrooms. J. Food Comp. Anal. 63, 171-183.

Schmidt, C.V., Brønnum, L. B., Sun, Y.-T., Faxholm, P. L., Flore, R., Clausen, M.P., Olsen, K., Mouritsen, O.G., 2018. Spise blæksprutter - er du mør? Akt. Nat. 3, 1217.

Schultz, J., Regardz, B., 1987. Calamari Cookbook: Exploring the World's Cuisines Through Squid. Celestialarts, Berkeley, CA.

Storelli, M.M., Giacominelli-Stuffler, R., Storelli, A., Marcotrigiano, G.O., 2006. Cadmium and mercury in cephalopod molluscs: Estimated weekly intake. Food Add. Cont. 23, 25-30.

Storelli, M.M., Garofalo, R., Giungato, D., Giacominelli-Stuffler, R., 2010. Intake of essential and non-essential elements from consumption of octopus, cuttlefish and squid. Food Add. Cont. Part B 3, 14-18.

UIC, 2018. Umami Information Center, Tokyo. https://www.umamiinfo.com/richfood/foodstuff/seafood.php\#ANCHOR08. Accessed on August 24, 2018.

WoRMS, 2018. World Register of Marine Species. http://www.marinespecies.org. Accessed on August 24, 2018.

Yamaguchi, S., Yoshikawa, T., Ikeda, S., Ninomiya, T., 1971. Measurement of the relative taste intensity of some L- $\alpha$-amino acids and 5'-nucleotides. J. Food Sci. $36,846-849$.

Yamaguchi, S., Ninomiya, K., 2000. Umami and food palatability. Amer. Soc. Nutr. Sci. 130, 921S-926S.

Zhang, F.B., Klebansky, B., Fine, R.M., Xu, H., Pronin, A., Liu, H., Tachdjian, C., Li, X., 2008. Molecular mechanism for the umami taste synergism. Proc. Natl. Acad. 
Sci. USA, 105, 20930-20934.

\section{Table}

Table 1. Cephalopod species observed in Danish waters with indication of prevalence, seasonal occurrence, edibility, and typical size and mass. Some of the data for prevalence and seasonal occurrence may be imprecise (e.g., some estimates of mantle size are larger than the equivalent full body estimate) since it is based on qualitative estimates and anecdotal evidence, some possibly outdated. The seasonal variation is graded on a scale 1-10 with a corresponding variation in colour tone. Sources: Muus (1959), Jensen and Knudsen (1995), Jensen (2005), Jereb and Roper (2005; 2010), Jereb et al. (2016), DanBIF (2018), and WoRMS (2018).

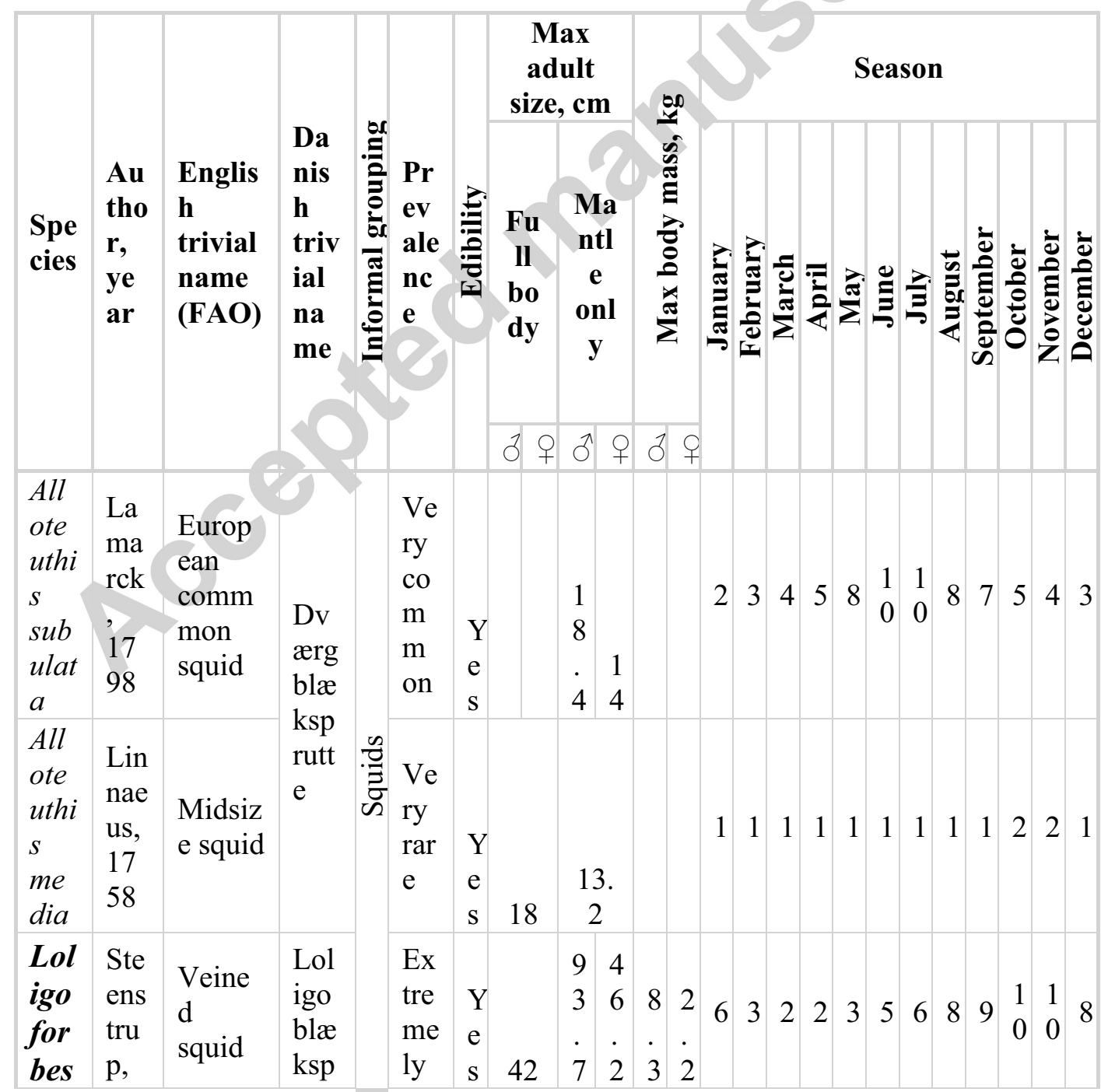




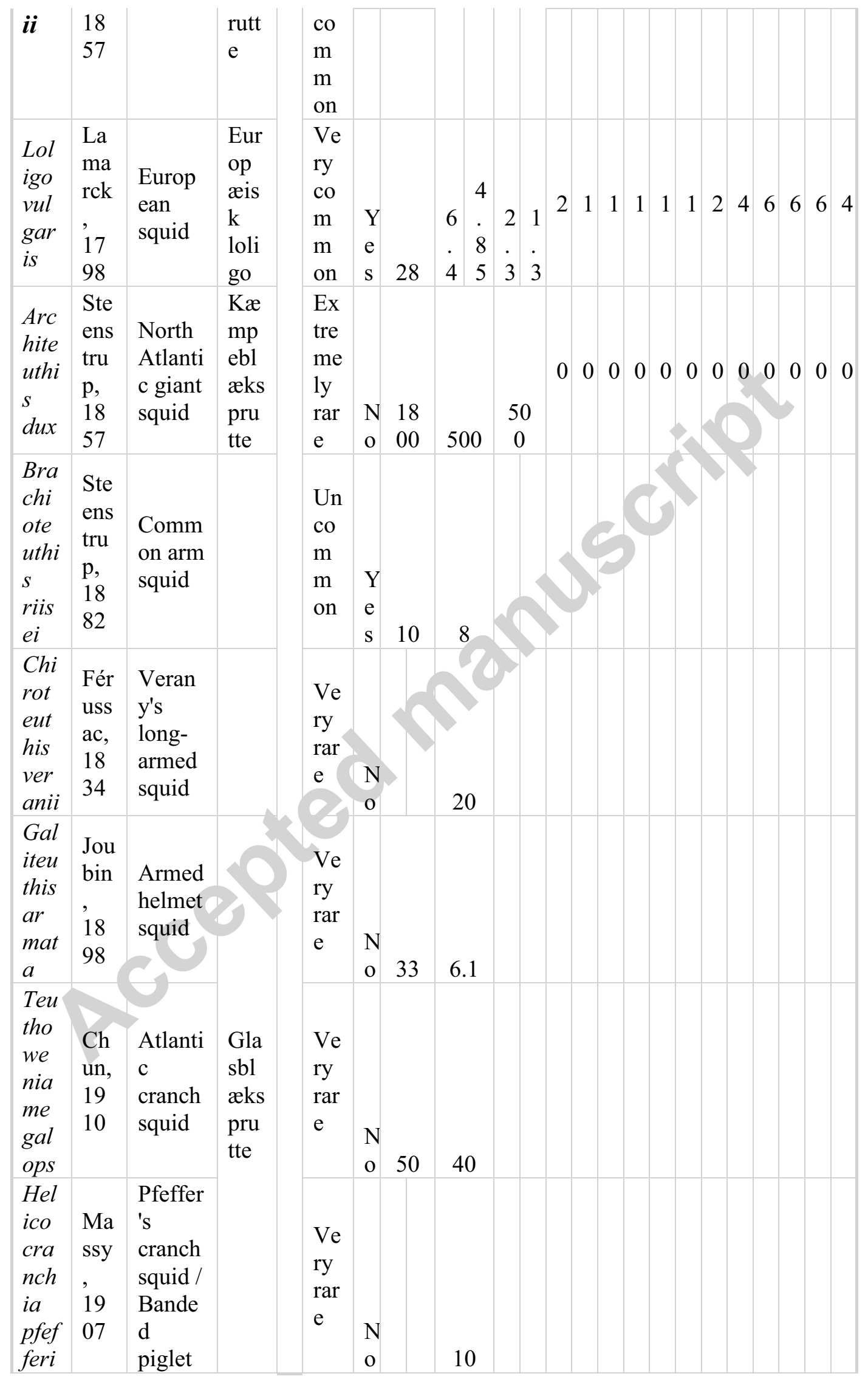




\begin{tabular}{|c|c|c|c|c|c|c|c|c|c|c|c|c|c|c|c|c|c|c|c|}
\hline & & squid & & & & & & & & & & & & & & & & & \\
\hline $\begin{array}{l}\text { Cyc } \\
\text { lote } \\
\text { uthi } \\
\text { s } \\
\text { sirv } \\
\text { enti }\end{array}$ & $\begin{array}{l}\text { Jou } \\
\text { bin } \\
, \\
19 \\
19\end{array}$ & $\begin{array}{l}\text { Sirven } \\
\text { t's } \\
\text { disc- } \\
\text { fin } \\
\text { squid }\end{array}$ & & $\begin{array}{l}\text { Ve } \\
\text { ry } \\
\text { rar } \\
\text { e }\end{array}$ & $\begin{array}{l}\mathrm{Y} \\
\mathrm{e} \\
\mathrm{s}\end{array}$ & & 50 & & & & & & & & & & & & \\
\hline $\begin{array}{l}\text { Go } \\
\text { nat } \\
\text { us } \\
\text { fab } \\
\text { rici } \\
i\end{array}$ & $\begin{array}{l}\text { Lic } \\
\text { hte } \\
\text { nst } \\
\text { ein } \\
\text { } \\
18 \\
18\end{array}$ & $\begin{array}{l}\text { Boreo- } \\
\text { Atlanti } \\
\text { c } \\
\text { armho } \\
\text { ok (or } \\
\text { "gonat } \\
\mathrm{e}^{\text {") }} \\
\text { squid }\end{array}$ & & $\begin{array}{l}\mathrm{Ra} \\
\mathrm{re}\end{array}$ & $\begin{array}{l}\mathrm{Y} \\
\mathrm{e} \\
\mathrm{s}\end{array}$ & 28 & 40 & & & 1 & 1 & 2 & 2 & $\begin{array}{lll}1 & 1\end{array}$ & 12 & 23 & 4 & 4 & 42 \\
\hline $\begin{array}{l}\text { Go } \\
\text { nat } \\
\text { us } \\
\text { stee } \\
\text { nstr } \\
\text { upi }\end{array}$ & $\begin{array}{l}\text { Kri } \\
\text { ste } \\
\text { nse } \\
\text { n, } \\
19 \\
81\end{array}$ & $\begin{array}{l}\text { Atlanti } \\
\text { c } \\
\text { gonate } \\
\text { squid }\end{array}$ & & $\begin{array}{l}\mathrm{Ra} \\
\text { re }\end{array}$ & $\begin{array}{l}\mathrm{Y} \\
\mathrm{e} \\
\mathrm{S}\end{array}$ & 41 & 19 & & & & & & & & & & & & \\
\hline $\begin{array}{l}\text { His } \\
\text { tiot } \\
\text { eut } \\
\text { his } \\
\text { bon } \\
\text { nell } \\
\text { ii }\end{array}$ & $\begin{array}{l}\text { Fér } \\
\text { uss } \\
\mathrm{ac}, \\
18 \\
34\end{array}$ & $\begin{array}{l}\text { Umbre } \\
\text { lla } \\
\text { squid }\end{array}$ & & $\begin{array}{l}\text { Ve } \\
\text { ry } \\
\text { rar } \\
\text { e }\end{array}$ & $\begin{array}{l}\mathrm{Y} \\
\mathrm{e} \\
\mathrm{s}\end{array}$ & & 33 & & & & & & & & & & & & \\
\hline $\begin{array}{l}\text { Ne } \\
\text { ote } \\
\text { uthi } \\
\text { s } \\
\text { thie } \\
\text { lei }\end{array}$ & $\begin{array}{l}\mathrm{Na} \\
\text { ef, } \\
19 \\
21\end{array}$ & $\begin{array}{l}\text { Thiele' } \\
\text { s new } \\
\text { squid }\end{array}$ & & $\begin{array}{l}\text { Ve } \\
\text { ry } \\
\text { rar } \\
\text { e }\end{array}$ & $\begin{array}{l}\mathrm{N} \\
\mathrm{O}\end{array}$ & & 10 & & & & & & & & & & & & \\
\hline $\begin{array}{l}\text { Tan } \\
\text { ingi } \\
a \\
\text { dan } \\
\text { ae }\end{array}$ & $\begin{array}{l}\text { Jou } \\
\text { bin } \\
1 \\
19 \\
31\end{array}$ & $\begin{array}{l}\text { Taning } \\
\text { 's } \\
\text { octopu } \\
\text { s squid }\end{array}$ & & $\begin{array}{l}\text { Ve } \\
\text { ry } \\
\text { rar } \\
\text { e }\end{array}$ & $\begin{array}{l}\mathrm{Y} \\
\mathrm{e} \\
\mathrm{s}\end{array}$ & & 170 & & $\begin{array}{l}16 \\
1.4\end{array}$ & & & & & & & & & & \\
\hline $\begin{array}{l}\text { Ille } \\
x \\
\text { coi } \\
\text { nde } \\
\text { tii }\end{array}$ & $\begin{array}{l}\text { Vé } \\
\text { ran } \\
y, \\
18 \\
39\end{array}$ & $\begin{array}{l}\text { Southe } \\
\text { rn (or } \\
\text { "broad } \\
\text { tail") } \\
\text { shortfi } \\
\text { n } \\
\text { squid }\end{array}$ & $\begin{array}{l}\text { Rø } \\
\mathrm{d} \\
\text { blæ } \\
\text { ksp } \\
\text { rutt } \\
\text { e }\end{array}$ & $\begin{array}{l}\mathrm{Ra} \\
\mathrm{re}\end{array}$ & $\begin{array}{l}\mathrm{Y} \\
\mathrm{e} \\
\mathrm{s}\end{array}$ & 27 & $\begin{array}{l}2 \\
7 \\
. \\
9\end{array}$ & $\begin{array}{l}3 \\
7\end{array}$ & & 1 & 1 & 2 & 3 & $\begin{array}{lll}2 & 1\end{array}$ & $\begin{array}{ll}1 & 1\end{array}$ & $\begin{array}{ll}1 & 1\end{array}$ & 2 & 3 & 2 \\
\hline $\begin{array}{l}\text { Om } \\
\text { ma } \\
\text { stre }\end{array}$ & $\begin{array}{l}\text { Le } \\
\text { sue } \\
\text { ur, }\end{array}$ & $\begin{array}{l}\text { Red } \\
\text { (or } \\
\text { "neon" }\end{array}$ & $\begin{array}{l}\text { Rø } \\
\text { d } \\
\text { fly }\end{array}$ & $\begin{array}{l}\text { Ve } \\
\text { ry } \\
\text { rar }\end{array}$ & $\begin{array}{l}\mathrm{Y} \\
\mathrm{e} \\
\mathrm{s}\end{array}$ & $\begin{array}{c}15 \\
0\end{array}$ & $\begin{array}{l}4 \\
2\end{array}$ & $\begin{array}{l}9 \\
0\end{array}$ & $\begin{array}{ll}2 & \\
. & 2 \\
2 & 5\end{array}$ & $\begin{array}{ll}2 & 1 \\
5 & \end{array}$ & 1 & 1 & 2 & 22 & 22 & 23 & 2 & 2 & 22 \\
\hline
\end{tabular}




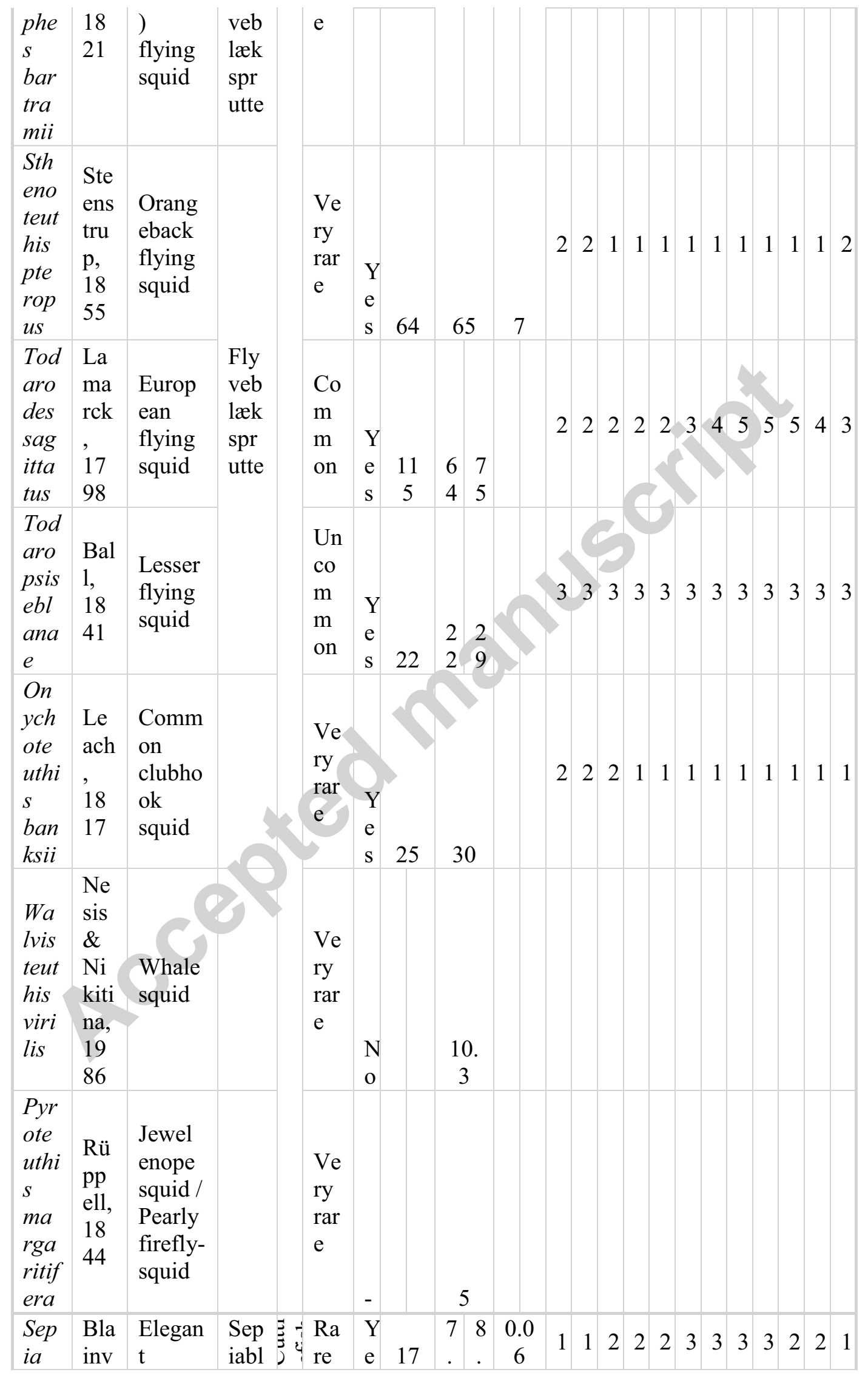




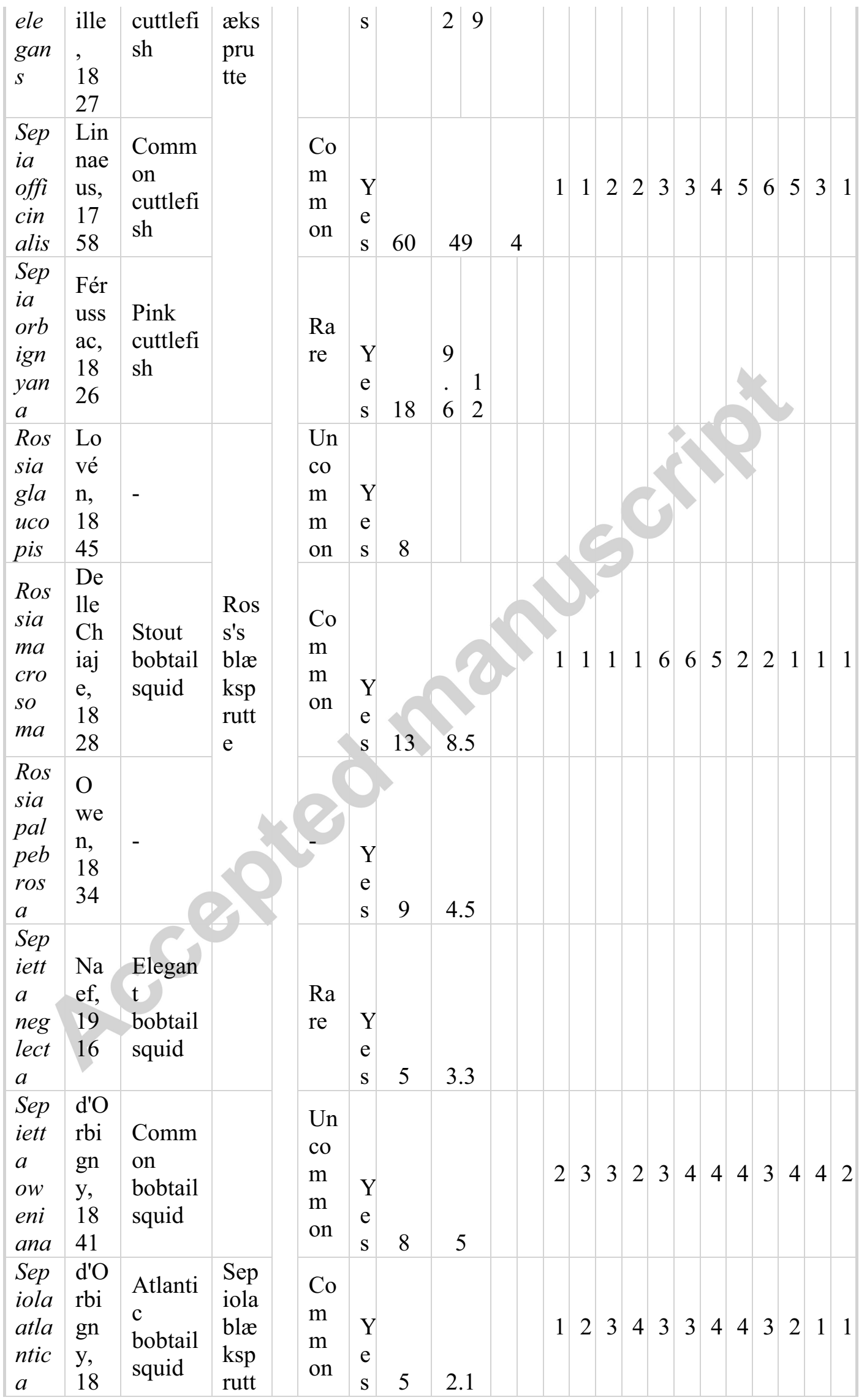




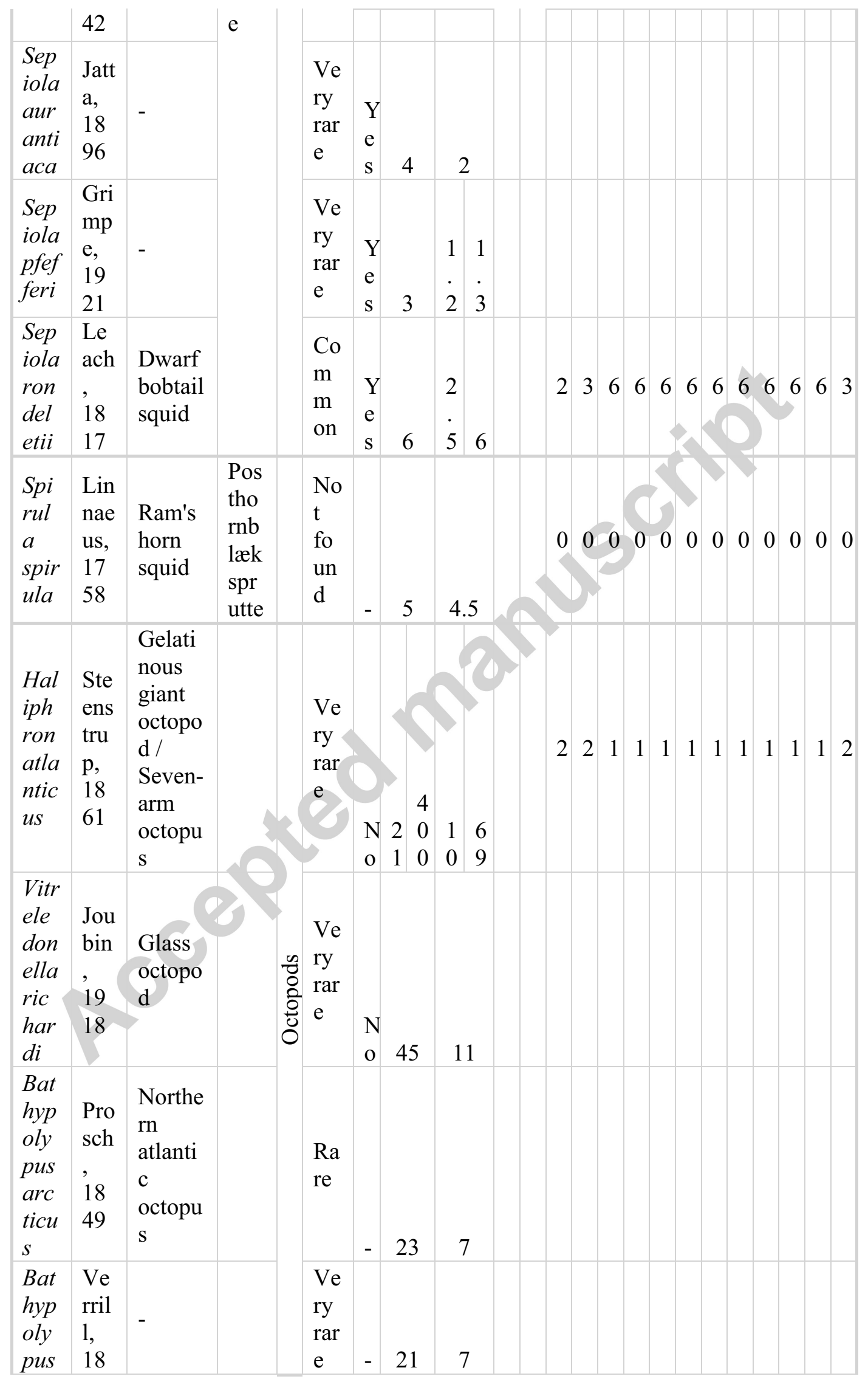




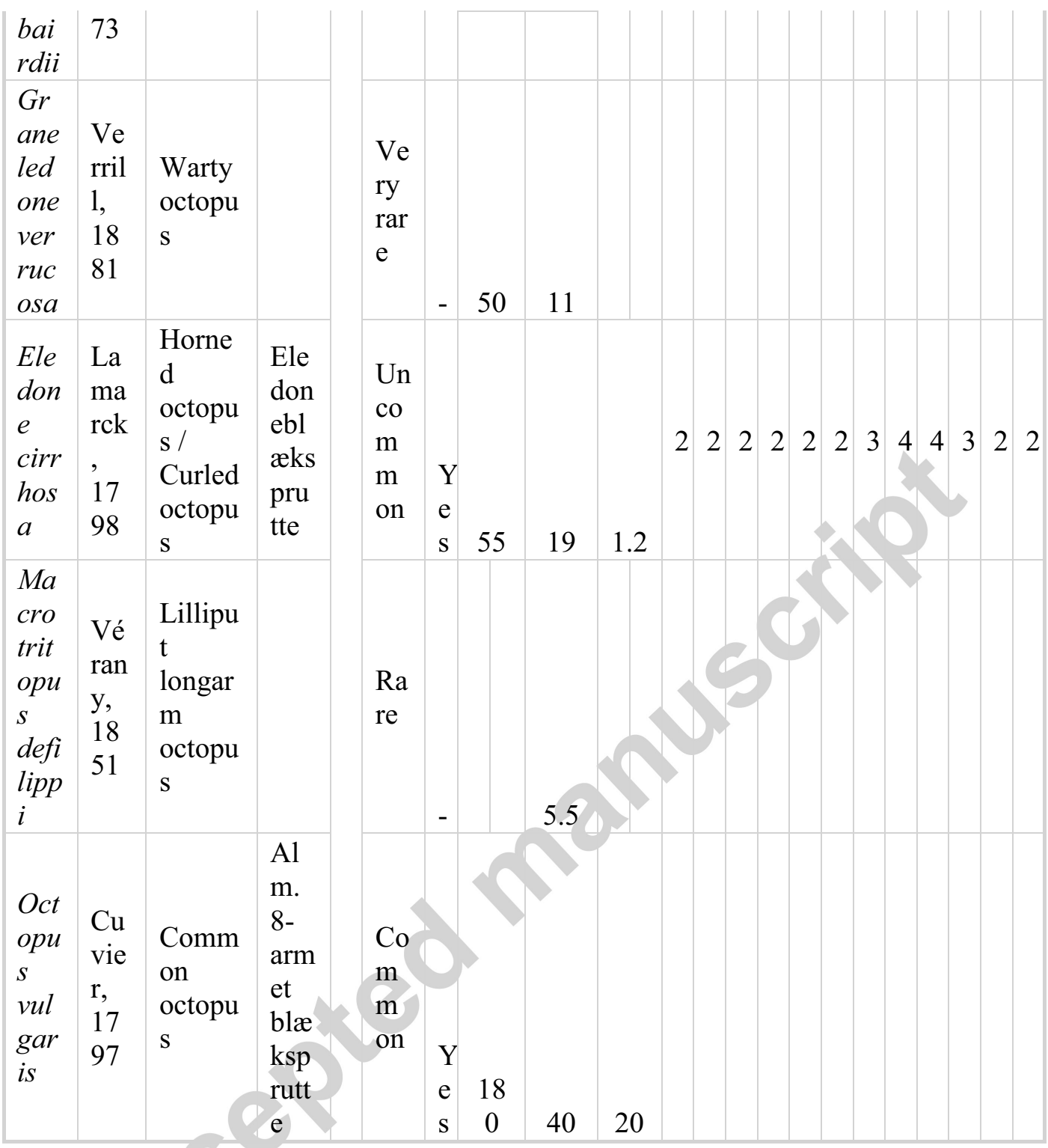

\section{Figures}

Fig. 1. Phylogenetic tree of cephalopods found in waters around Denmark (including Spirula spirula), highlighting the species Loligo forbesii that is the main focus of the present paper. Sources: Jereb and Roper (2005; 2010), Jereb et al. (2016), and WoRMS (2018). 
Fig. 2. Specimen of Loligo forbesii where the mantle is cut open to display part of the innards, including ink sack, hepatopancreas (liver), and gills. The chitin gladius has been removed and is shown on the side. (Permission to print by courtesy of Jonas Drotner Mouritsen.)

Fig. 3. The eight arms and two tentacles of a specimen of Loligo forbesii with the buccal mass and the beak at the centre. One of the arms show a clear hectocotylus with absent suckers at the end of the arm. (Permission to print by courtesy of Jonas Drotner Mouritsen.)

Fig. 4. Schematic illustration of the anatomy of a squid. (Permission to print by courtesy of Jonas Drotner Mouritsen.)

Fig. 5. Second-harmonic microscopy images of collagen structure of the squid mantle. The scale bars correspond to $50 \mu \mathrm{m}$. Before (A) and after (B) sous vide treatment at $55^{\circ} \mathrm{C}$ for $30 \mathrm{~min}$.

Fig. 6. Sectioning of squid mantle for texture analysis.

Fig. 7. Force versus time at loading rate $2 \mathrm{~mm} / \mathrm{s}$ for a squid mantle sample before and after sous vide treatment $\left(55^{\circ} \mathrm{C}\right.$ for $0.5,1.0$, and $\left.1.5 \mathrm{hrs}\right)$.

Fig. 8. Free- and total amino acid composition of raw squid mantle.

Fig. 9. Raw squid paste on Sardinian pane carasau. (Permission to print by courtesy of Jonas Drotner Mouritsen.)

Fig. 10. 'Silk squid' (curly mantle confit) of squid mantle strips. (Permission to print by courtesy of Jonas Drotner Mouritsen.)

Fig. 11. Braided squid tentacles, steamed, cold smoked, and cured. (Permission to print by courtesy of Jonas Drotner Mouritsen.) 
Fig. 12. Semi-dry squid mantles that have been cut in strips and grilled. (Permission to print by courtesy of Jonas Drotner Mouritsen.)

Fig. 13. Canned prototype product of prepared, small squid arms in oil. Label design with gyotaku print of the squid tentacle club. (Permission to print by courtesy of Jonas Drotner Mouritsen.) 


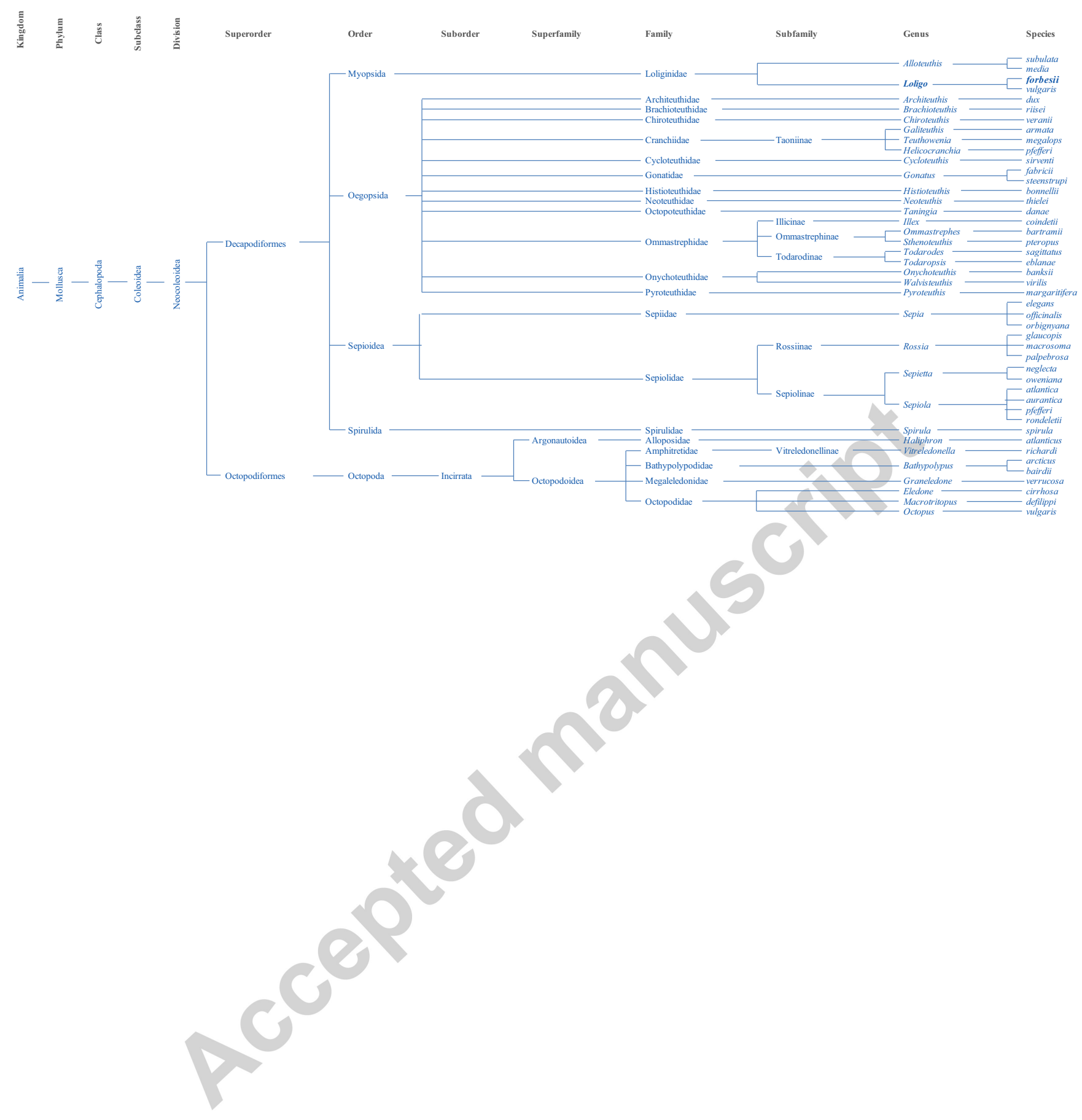




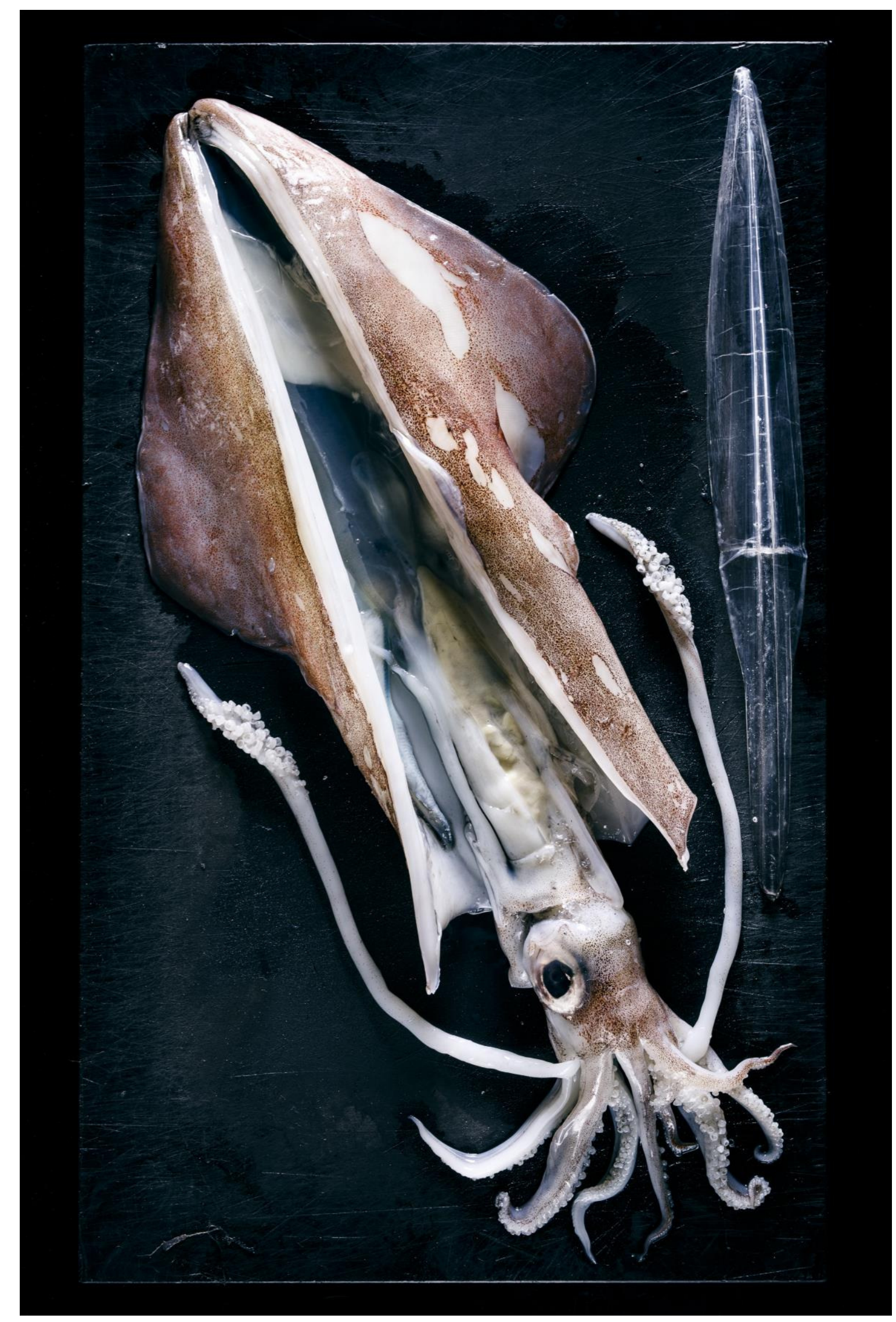




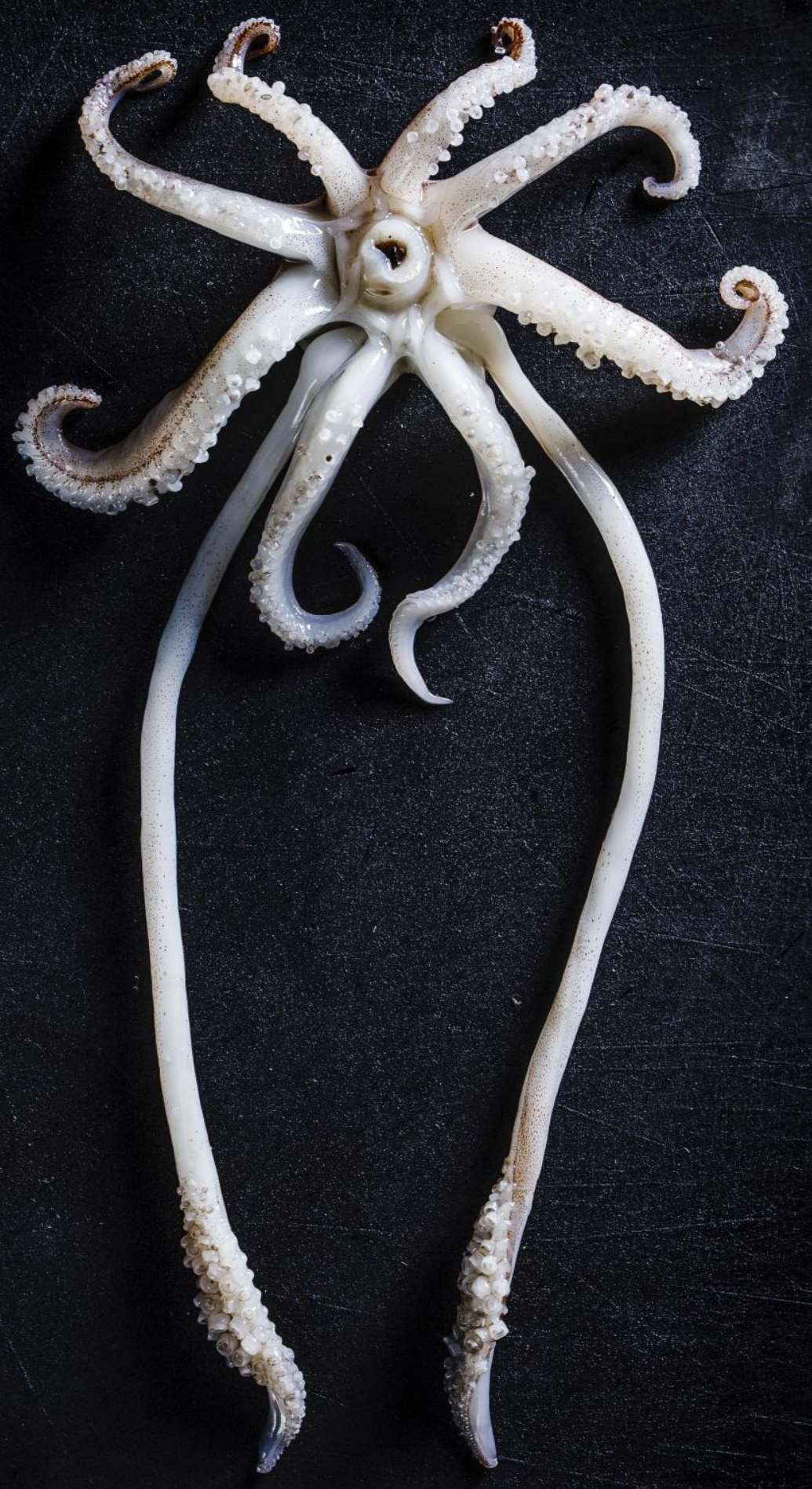



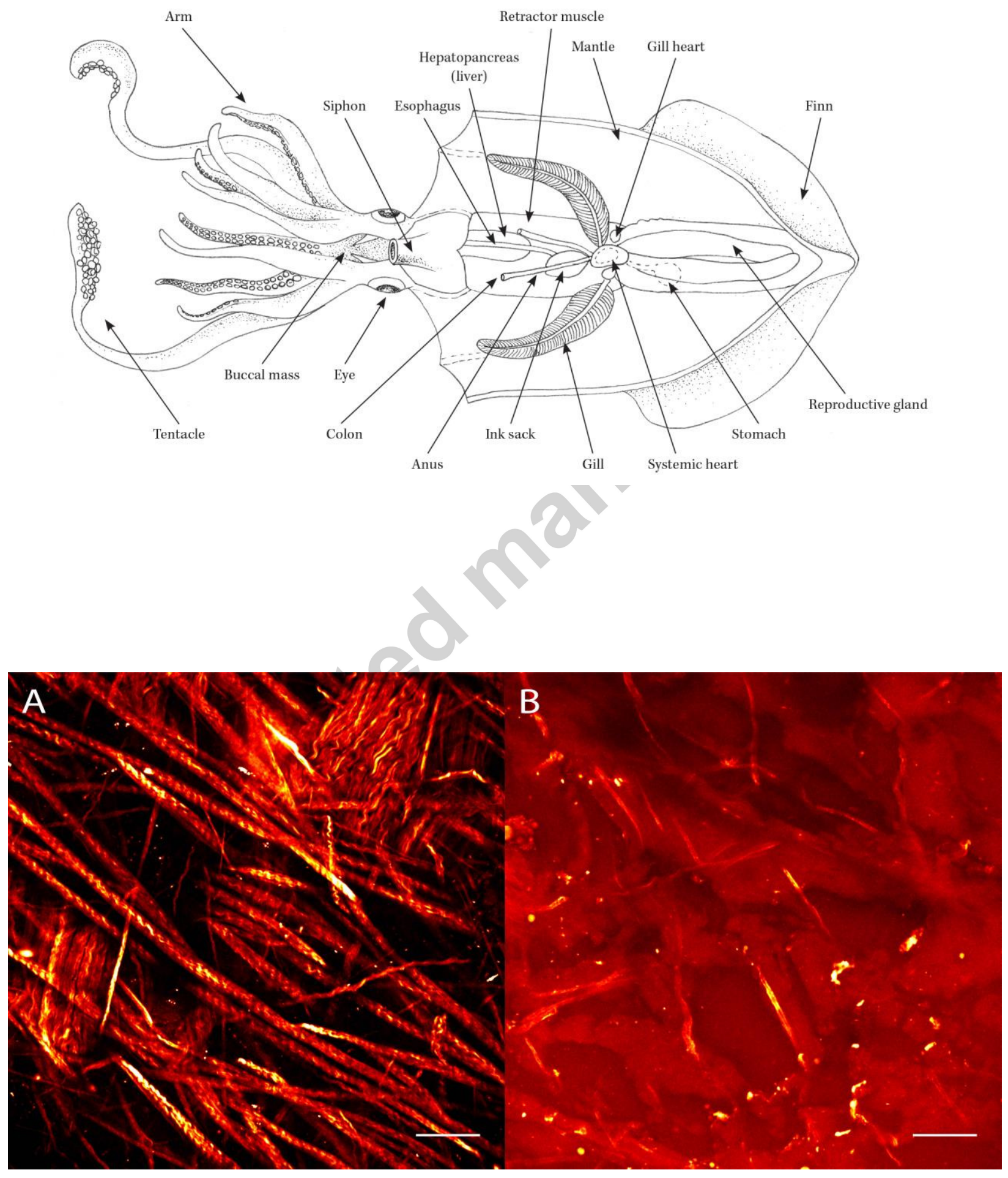


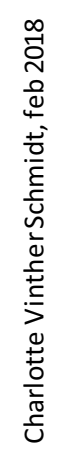

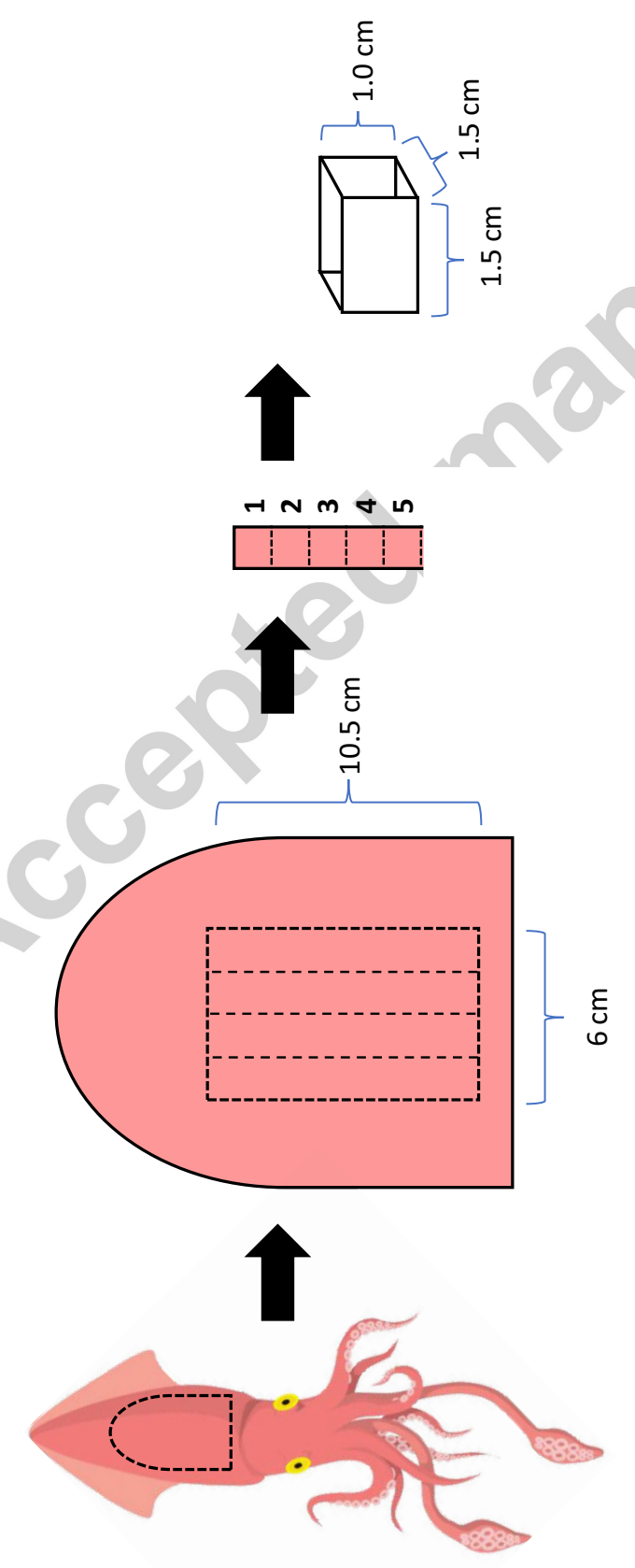




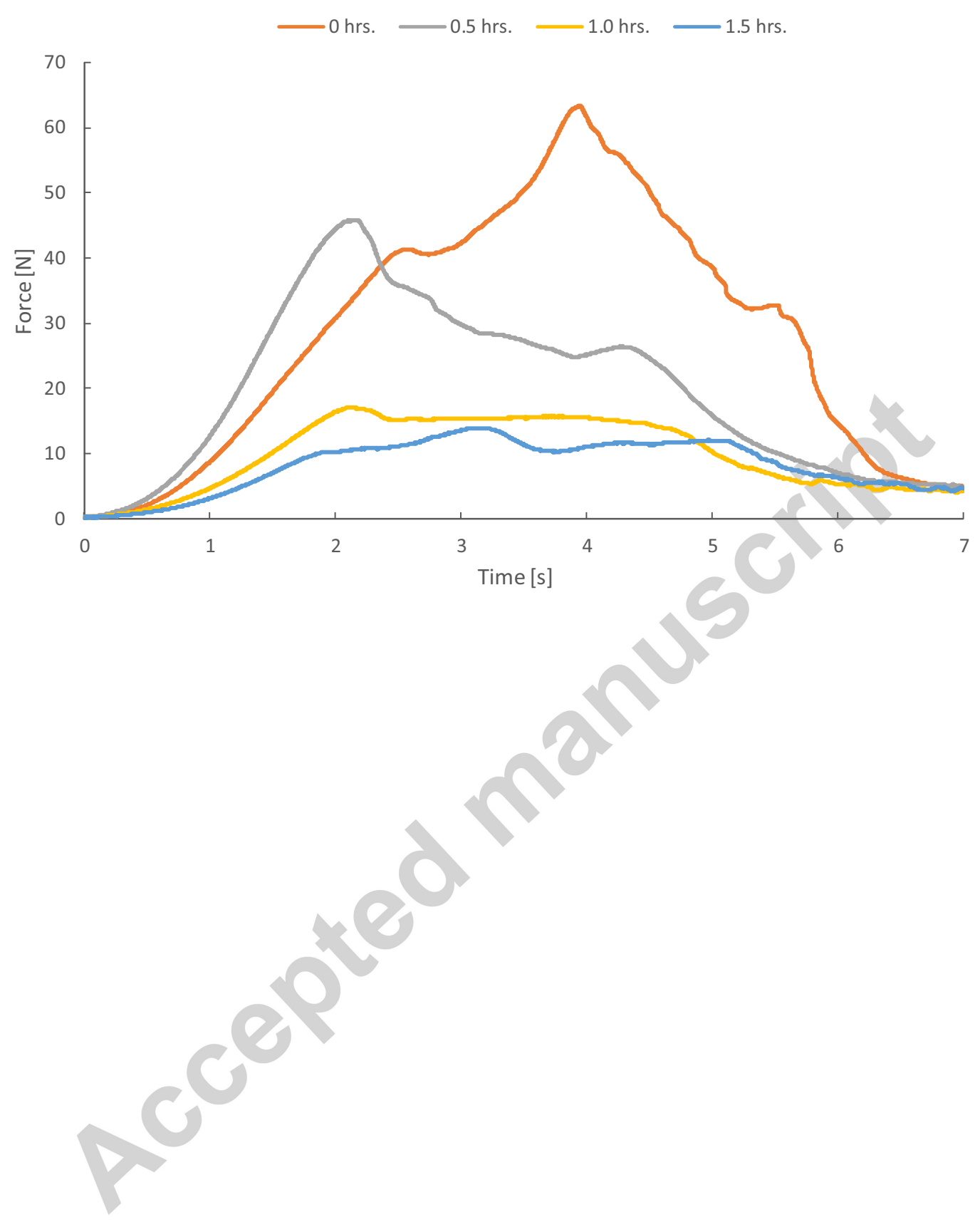




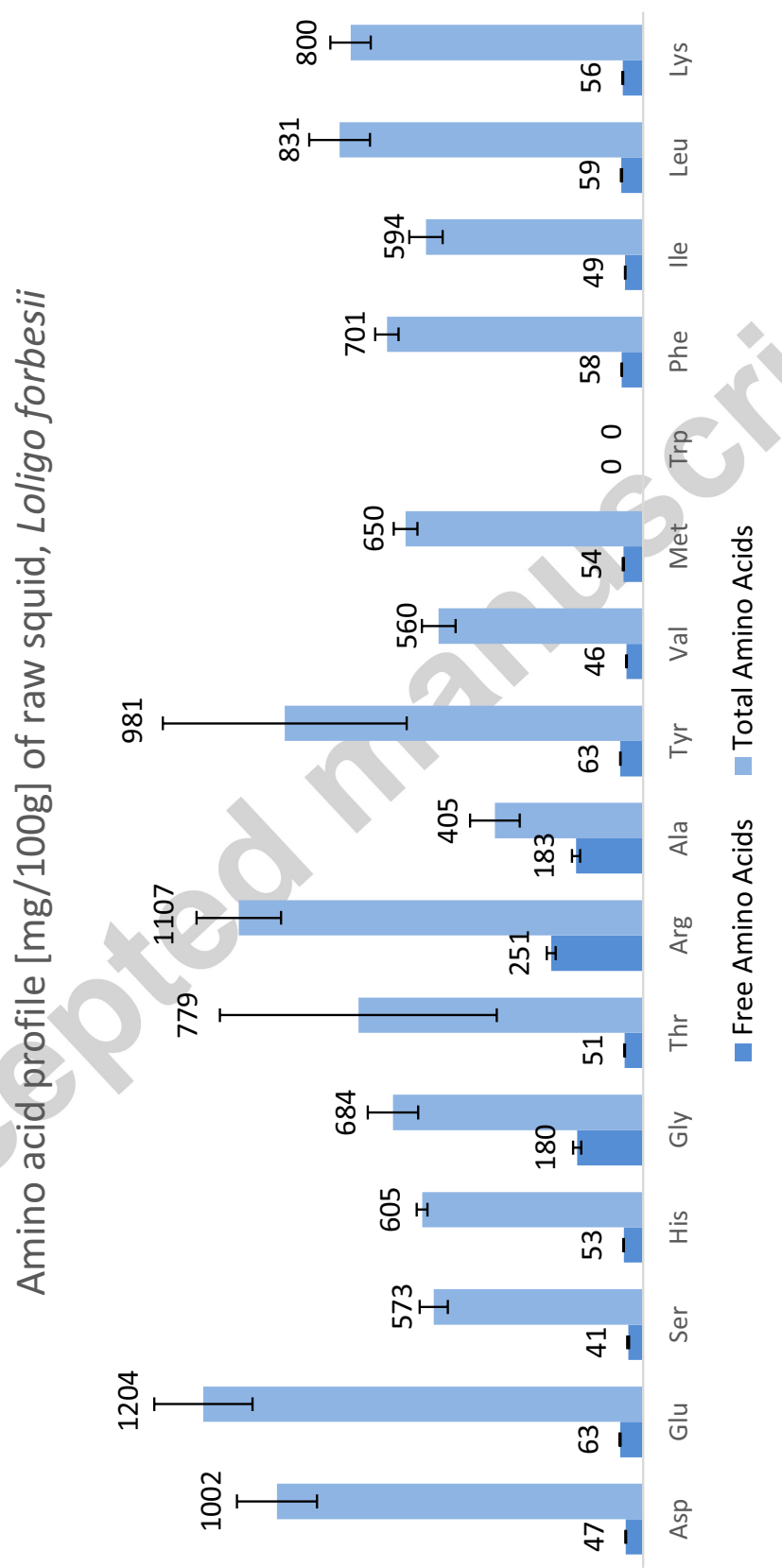




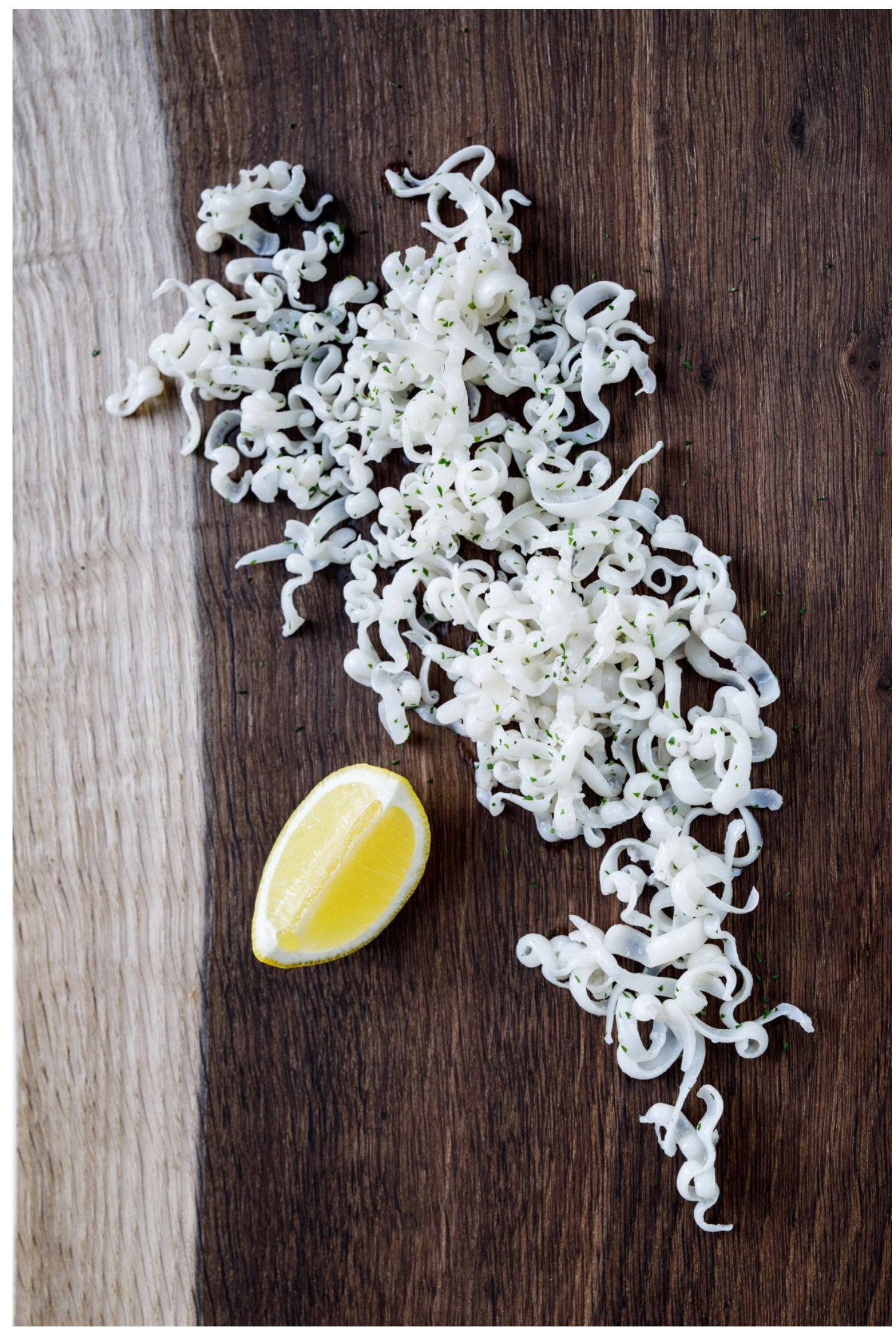




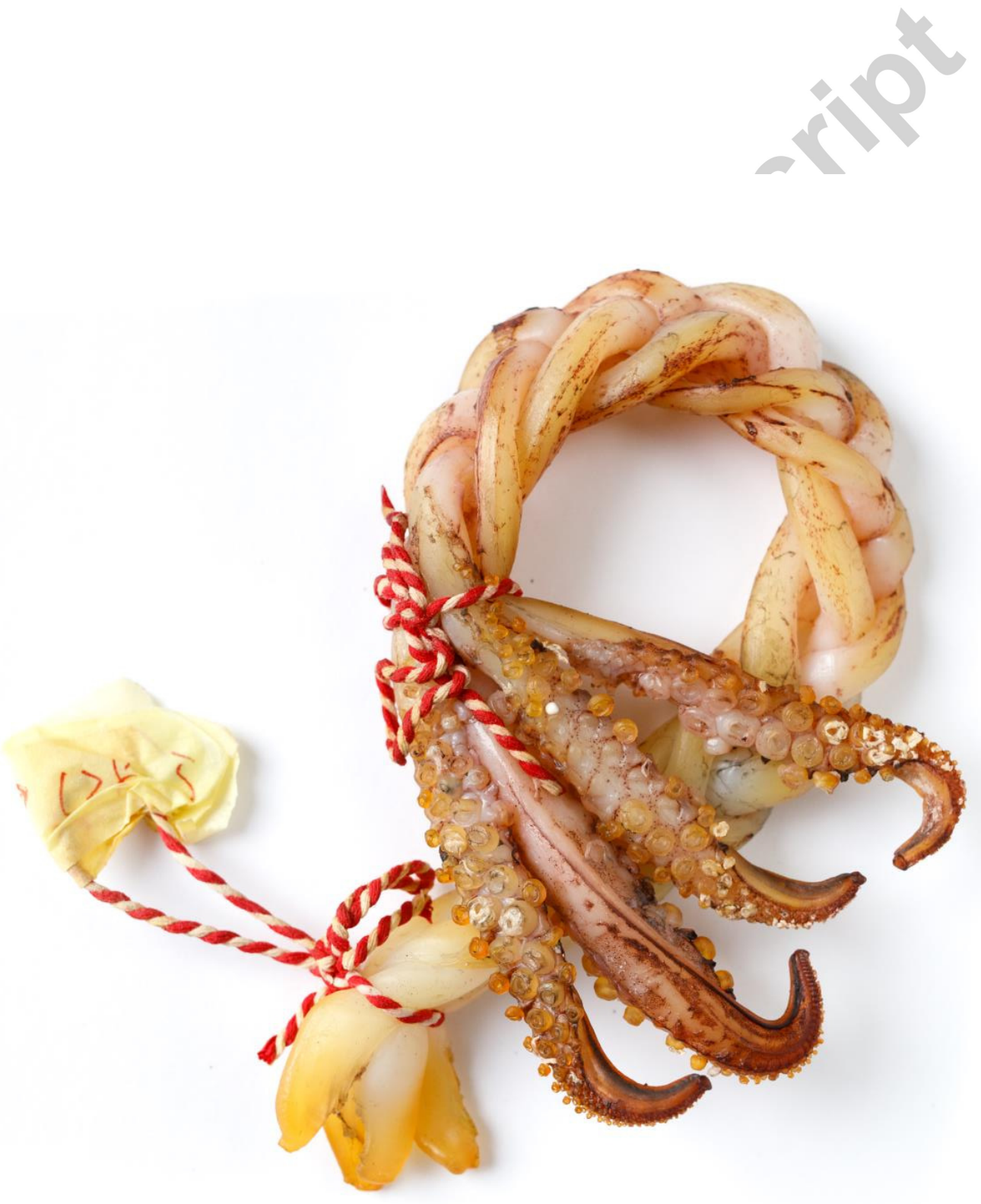




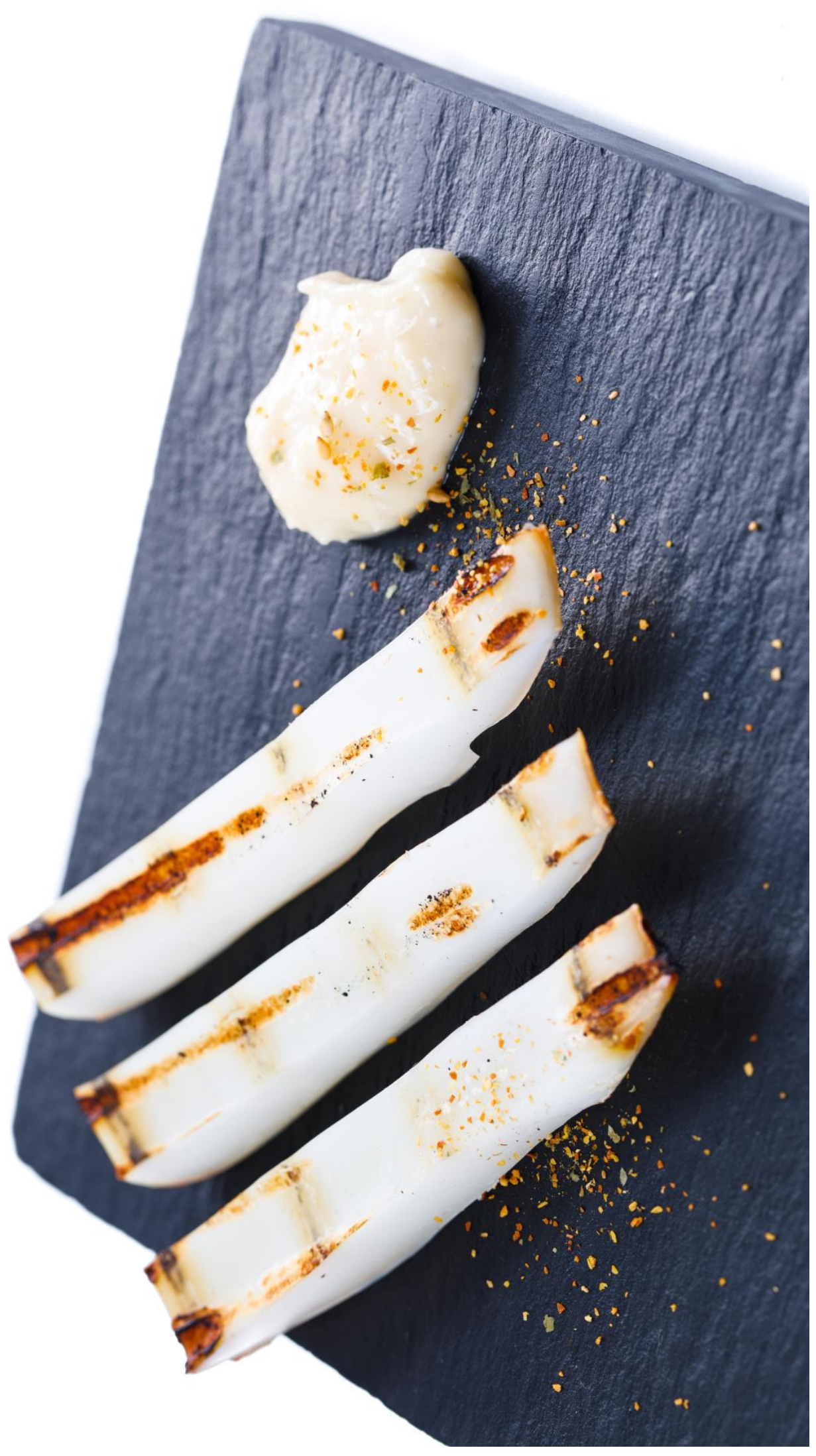




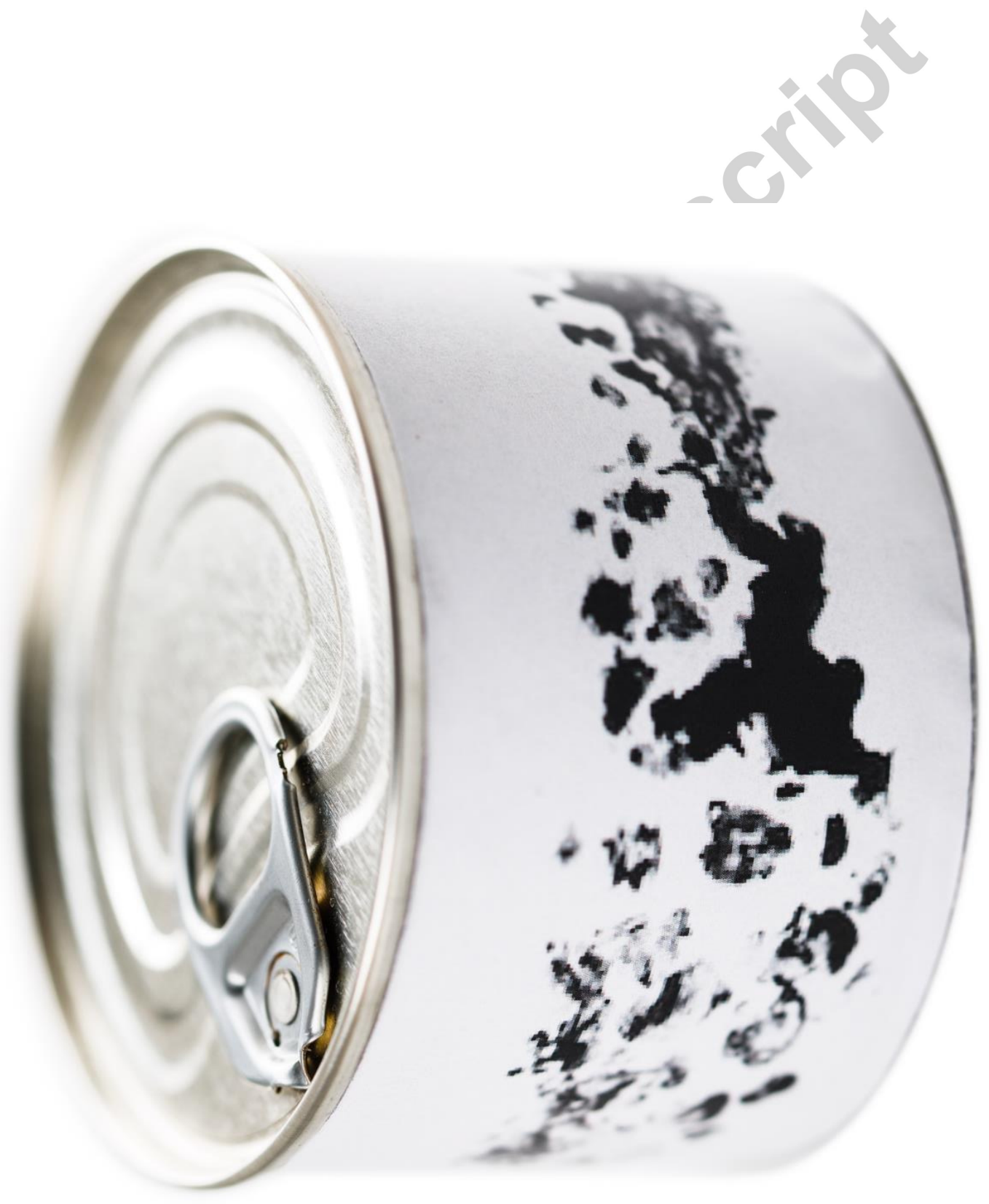

